\title{
Bioactive compounds derived from echinoderms
}

Cite this: RSC Adv., 2014, 4, 29365

Received 13th April 2014

Accepted 12th June 2014

DOI: $10.1039 / \mathrm{c} 4 \mathrm{ra03352c}$

www.rsc.org/advances

\author{
Ana R. Gomes, ${ }^{* a}$ Ana C. Freitas, ${ }^{\text {ab }}$ Teresa A. P. Rocha-Santos ${ }^{a b}$ \\ and Armando C. Duarte ${ }^{\mathrm{b}}$
}

The marine environment provides a rich source of natural products with potential therapeutic applications. The rate of studies in marine animals, particularly invertebrates has increased considerably in the last few years leading to an increase in the number of bioactive compounds discovered. In this context, this review focuses on the phylum Echinodermata and aims at summarizing and highlighting the bioactive compounds derived from the echinoderms discovered between 2009 and 2013, clarifying their structure, distribution, biosynthetic origin, and biological activity.

\section{Introduction}

Nature is an ancient pharmacy, rich in bioactive compounds (BC) with several biological properties (bioactivities). ${ }^{1}$ Responsible for more than $70 \%$ of the Earth's surface, the oceans are an enormous source of potential therapeutic agents. ${ }^{2-4}$ The marine environment is extremely complex, showing immense biodiversity. ${ }^{5}$ Numerous new natural compounds have been isolated from marine invertebrates, such as echinoderms with interesting pharmaceutical activities and a broad spectrum of biological activity. ${ }^{6}$ The importance of these echinoderms as a promising source of bioactive compounds for development of pharmaceuticals and potential therapeutic applications has been growing rapidly., ${ }^{2,3,7,8}$ The echinoderms are a phylum containing about 7000 living species and 13000 extinct.9,10 The

${ }^{a}$ ISEIT/Viseu, Instituto Piaget, Estrada do Alto do Gaio, Galifonge, 3515-776 Lordosa, Viseu, Portugal. E-mail: aaritagomes@gmail.com; Fax: +351-232-910-180; Tel: +351232-910-100

${ }^{b}$ Department of Chemistry and CESAM, University of Aveiro, Campus de Santiago, 3810-193 Aveiro, Portugal current echinoderms are divided into five classes: Holothuroidea (sea cucumbers), Asteroidea (starfishes), Echinoidea (sea urchins and sand dollars), Crinoidea (crinoids and sea lilies), and Ophiuroidea (brittle stars and basket stars). ${ }^{5,11}$ The bioactive compounds derived from echinoderms are compounds of interest showing an extensive application in the treatment of many diseases. ${ }^{12,13}$ Those compounds showed several biological properties, such as antibacterial, anticoagulant, antifungal, antimalarial, antiprotozoal, anti-tuberculosis, anti-inflammatory, anti-tumor, anti-HIV and antiviral activities. ${ }^{6,12-17}$

The $\mathrm{BC}$ are considered chemical compounds derived and isolated from biological sources and therefore, marine natural bioactive compounds (MNBC) are compounds isolated from marine sources. Some of the $\mathrm{BC}$ can also be referred to as secondary metabolites, that is, small molecules with molecular weight (MW) less than $2 \mathrm{kDa}$ produced by an organism, and not essential for its survival. ${ }^{18}$

Recently, much attention has been paid to unraveling the structural, compositional and sequential properties of BC. ${ }^{2}$ Based on structural information, these compounds can be subdivided according to Schmitz's chemical classification into

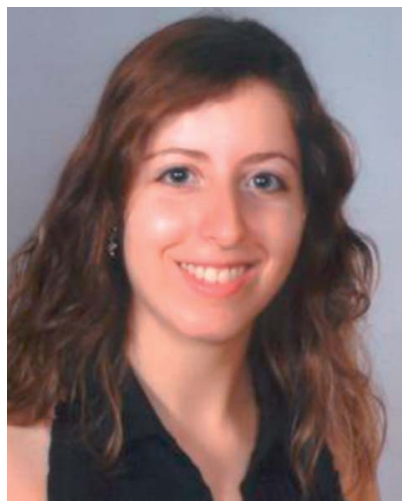

MSc Ana Rita Gomes has graduated in Biochemistry (2010) and obtained her post-graduate master's degree in Biochemistry (2012), both at the University of Coimbra, Portugal. During the period of 2012 to 2014 she was research fellow at the Instituto Piaget, Portugal.

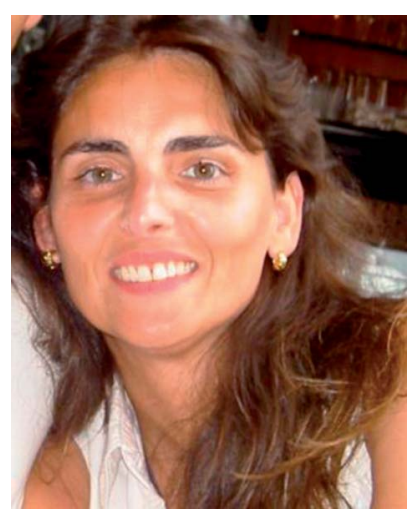

Dr Ana C. Freitas has graduated in Food Engineering (1991) and obtained her PhD in Biotechnology (1999), both at Catholic University of Oporto. Since then, she is Assistant Professor at the Instituto Piaget, Portugal. From 2011, she is an integrated member at CESAM Research Centre, University of Aveiro, Portugal. 
six major chemical classes, namely, polyketides, terpenes, peptides, alkaloids, shikimates, and sugars. ${ }^{6,19}$ However, many other classes of marine-sourced compounds have also been reviewed to varying extents, including briarane-type diterpenoids, cyclic polypeptides containing b-amino acid fragments, alkaloids, pyrroloiminoquinone alkaloids, guanidines, ascidian-derived alkaloids, 2-aminoimidazole alkaloids, antitumour peptides, kahalalides, carotenoids, $\alpha$-conotoxins, cladiellins, asbestinins, briarellins, eleutherobins, fuscosides, pseudopterosins, sesquiterpenoids, triterpenoids, and disesquiterpenoids. $^{20}$ Still others, such as halogenated, marine toxins, glycosphingolipids, polyketides, sterols, imidazole, oxazole, thiazole alkaloids, ribosomal peptides, phospholipids, terpenyl-purines, non-methylene-interrupted fatty acids, antimicrobial peptides, alkaloids with a non-rearranged monoterpenoid unit, diterpenoids and conotoxins. ${ }^{21,22}$

Several reviews have been published on bioactive natural products derived from different organisms such as microalgae, fungi, mussels, shellfish, and starfish. ${ }^{23-27}$ Concerning the MNBC derived from echinoderms, some of the information has been included in general reviews published from 2009 to 2011 by Blunt et al. ${ }^{20-22}$ Thus, the main goal of this review is gathering information of the new natural compounds, with special emphasis on $\mathrm{BC}$, from echinoderms isolated over the last 5 years (2009 to 2013), describing their structure, distribution, biosynthetic origin, and bioactivity.

\section{General characteristics of echinoderms}

Echinoderms are a phylum of invertebrate marine animals (Phylum Echinodermata), which live exclusively in the marine habitat, distributed in almost all depths and latitudes, as well as reef environments or shallow shores, being characterized by their radial symmetry. ${ }^{9,28}$ During larval development an echinoderm has a distinct bilateral symmetry that is lost during metamorphosis; the radial symmetry appears only after the formation of the mesoderm. ${ }^{9,28,29}$

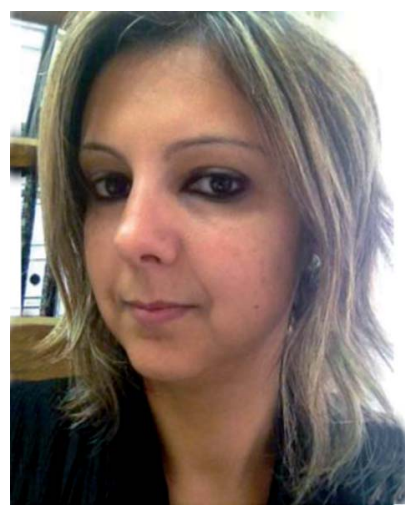

Dr Teresa Rocha-Santos has graduated in Analytical Chemistry (1996) and obtained $a \mathrm{PhD}$ in Chemistry (2000), both at the University of Aveiro, Portugal. In 2001 she was awarded with a prize for her PhD studies in the area of urban environment. She was an Assistant Professor at Instituto Piaget from 2000 to 2009. During the period of 2000 to 2009 she was the coordinator of environmental chemistry graduation course (5 year degree) at Instituto Piaget. Currently, she is an Associate Professor at Instituto Piaget (from May 2009) and an integrated member at CESAM - University of Aveiro.
The adult echinoderms have a water vascular system with external tube-feet, used mainly in locomotion, and a calcareous endoskeleton consisting of ossicles connected by a mesh of collagen fibers. ${ }^{9,28}$ The skeletal system is one of the most characteristic features of the echinoderms, which varies both in the arrangement details, as well as in their development extent, between five different classes. The skeletal plates have their origin in the mesoderm and near the surface of the body, directly beneath the outer body cover. Spines, frequently associated with these plates, suggest the meaning of the name Echinoderm which is in Latin, spiny skin., ${ }^{\mathbf{9} 28,29}$

The echinoderms are also known by their regeneration ability. Most sea cucumbers, starfishes and sea lilies often lose parts of their arms intentionally, when they feel threatened or during the asexual reproduction, which they can later regenerate. Sea urchins are constantly replacing spines lost by damage. ${ }^{30}$ In most of these species, asexual reproduction is by transverse fission with the disc splitting in two. Although in most species at least part of the disc is needed for complete regeneration, in a few species of starfishes, such as Sclerasterias euplecta and Linckia columbiae, a single severed arm can grow into a complete individual over a period of several months. Thus, an individual may have arms of varying lengths. ${ }^{31,32}$ Asexual reproduction by transverse fission has also been observed in adult sea cucumbers, such as Holothuria parvula. ${ }^{33}$ During echinoderms sexual reproduction, the eggs and sperm cells are typically released into open water, where fertilization takes place. Usually, the echinoderms are nearly all gonochoric, though a few species are hermaphroditic..$^{9,28,29}$

The current echinoderms are distributed into five different classes: Holothuroidea (sea cucumbers), Asteroidea (starfishes), Echinoidea (sea urchins and sand dollars), Crinoidea (crinoids and sea lilies) and Ophiuroidea (brittle stars and basket stars). ${ }^{9,29}$

\subsection{Class Holothuroidea}

The sea cucumbers are elongated echinoderms without a definite skeleton and pentaradial symmetry, with a mouth at one

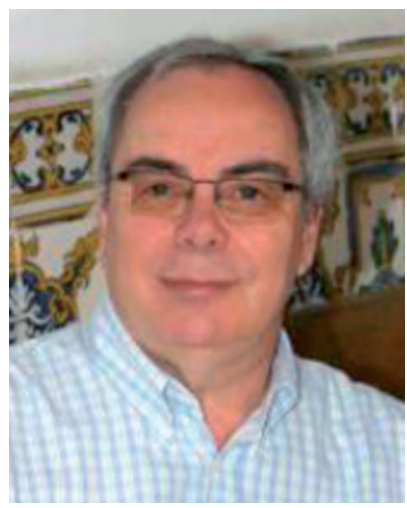

Prof. Armando C. Duarte graduated in Chemical Engineering (1977) at the University of Oporto (Portugal) and obtained a PhD in Public Health Engineering (1981) at the University of Newcastle-upon-Tyne (United Kingdom). In 2006, The Portuguese Science Foundation awarded him a prize for Scientific Excellence and in 2013 became a member of the FCT Scientific Council for Natural and Environmental Sciences. He is a Professor of Environmental \& Analytical Chemistry at the University of Aveiro (Portugal) since 1995. 
extremity surrounded by a circle of branched tentacles and an anus at the opposite extremity. ${ }^{28}$ Typically, the body is five sided and on each side bears a double row of tube-feet, used in locomotion. The body wall is highly muscular. The alternate use of longitudinal and circular muscles enables the cucumber to creep like a worm. ${ }^{29}$ Although there is no continuous skeleton, the body wall is rather firm, and this is in large measure due to the presence of microscopic calcareous plates embedded in the tissues. In some species, a calcareous ring of ten plates surrounds the esophagus and serves as a support for the tentacles. ${ }^{9,28}$

The diet of most cucumbers consists of plankton and decaying organic matter found in the sea. The digestive canal is held in definite position by mesenteries. The esophagus loads into a stomach which is then followed by a tubular intestine. From the walls of the cloaca, there is usually a pair of minutely branched respiratory trees which, by the muscular action of the cloaca, are filled with water and serve as respiratory organs. ${ }^{9,28,29}$

The sea cucumbers are dioecious with separate male and female individuals, which reproduce by releasing sperm and eggs into the ocean water. The reproductive system consists of a single gonad, consisting of a cluster of tubules emptying into a single duct that opens on the upper surface of the animal, close to the tentacles. In the development stages of the embryo is produced a larval form known as an auricularia.9,29

\subsection{Class Asteroidea}

Belonging to the class Asteroidea are the starfish or sea stars. These organisms are composed by a central disc from which usually five arms radiate, although some species may have more. They show a bilateral symmetry during larva phase, which is lost during metamorphosis, developing radial symmetry, typically pentamerism. ${ }^{\mathbf{2 8 , 2 9}}$ Located in the starfish body is the madreporite, a pore, responsible for the entry of water in a hydraulic system, named water vascular system, which is made up of a network of fluid-filled canals and is concerned with locomotion, adhesion, food manipulation and gas exchange. Mouth and anus are close together in the center of the disc on the underside of the starfish body, together with the water intake (madreporite). ${ }^{\mathbf{9} 28}$ The majority of starfishes is carnivorous and feed on sponges, bryozoans, ascidians, mollusks, bivalves and snails. Others feed on detritus, eating decomposed organic material and fecal matter. ${ }^{34}$ In the starfish feeding their stomach is everted through the mouth opening over the prey, thus surrounding the prey with the digestive organs. Digestive juices are secreted and the tissue of the prey is liquefied. The food mass is digested, and together with the stomach is again sucked through the mouth opening into the body. ${ }^{9,28}$ The starfishes are found in the ocean and at different depths. They can live in the coral reefs, and on sand or rocks. ${ }^{9}$

The starfish are well known by their regenerative ability. They are able to regenerate an entire new member (lost arms) or part of the central disc. The starfish are vulnerable to infections during the early stages after the loss of an arm, and the regrowth can take several months or years. The loss of parts of the body also can occur as a protective function, losing a body part to escape a predator (self-amputation) or during asexual reproduction.9,28,35
The starfishes are able to reproduce by sexual or asexual reproduction. In the sexual stage, the starfishes are simultaneous hermaphrodites, producing at the same time eggs and sperm. The eggs and sperm are released into the water and the embryos and larvae live as part of the plankton, or housed in rocks. ${ }^{29,36,37}$ In the asexual stage, the starfish may be able to reproduce by fission of their central discs or by of one or more of their arms..$^{29,37}$

\subsection{Class Echinoidea}

The sea urchins and sand dollars are usually globular, hemispherical, or disc-shaped., ${ }^{\mathbf{9} 28}$ The skeletal plates, named ambulacral areas are arranged in meridional bands, which bear openings through which the ambulacral feet protrude. The tube-feet are moved by a water vascular system, allowing the sea urchin to pump water in and out of the tube feet, enabling it to move. ${ }^{9,29}$ As sea urchins move slowly, they feed mostly on algae. Surrounding the mouth, there is a circular opening where the skeletal plates are replaced by a membrane termed the peristome. Normally, the anus is in the pole opposite to the mouth in a region called the periproct. Around the periproct, the genital plates alternate with the ocular plates, and one of the genital plates is modified to serve as a madreporite..$^{\mathbf{9} 28}$

Five teeth are visible in the center of the peristome, and the entire chewing organ is known as Aristotle's lantern. At the top of the lantern, a short esophagus is open, which leads into the stomach. ${ }^{38}$ The intestine bends backwards in the opposite direction to that of the course of the stomach and in the case of the sea urchin leads to a median dorsal anus, while in the sand dollars it passes along the posterior interambulacrum to an anal opening either on or close to the margin of the disc. ${ }^{28,29}$

The female's eggs float freely in the sea, and are fertilized by free-floating sperm released by males. The eggs fertilized develop into a free-swimming blastula embryo in as few as 12 hours, but several months are needed for the larva to complete its full development, which begins with the formation of the test plates around the mouth and anus. ${ }^{9,29}$

\subsection{Class Crinoidea}

The crinoids or sea lilies include three basic sections: the stem, the calyx, and the arms. ${ }^{29}$ The stem is composed of highly porous ossicles which are linked by ligamentary tissue. The calyx is usually a globular or cup-shaped capsule which contains the more important internal organs, such as the digestive and reproductive organs. The mouth is located at the top of the dorsal cup, while the anus is located peripheral to it. The arms exhibit pentaradial symmetry, with smaller ossicles than the stem and equipped with cilia which facilitate feeding by moving the organic media into the mouth. ${ }^{28,29}$

The mouth descends into a short oesophagus. There is no true stomach, since the oesophagus binds directly to the intestine, which runs in a single loop around the inside of the calyx. The end of the intestine opens into a short muscular rectum, which ascends towards the anus. ${ }^{9,28,39}$

Crinoids have male and female individuals, but have no true gonads, producing their gametes from genital canals. The eggs and sperm are release into the surrounding sea water. The 
fertilized eggs hatch, resulting in the formation of a freeswimming ciliated larva, in which there is no communication between the mouth and the "stomach". The larva does not feed, and it lasts only for a few days before settling in the bottom of the sea using an adhesive gland on its ventral surface. The larva then metamorphoses into an adult. ${ }^{9,28}$

\subsection{Class Ophiuroidea}

The brittle stars or serpent stars have highly flexible arms radiating from a central circular or pentagonal disc. The body outline is similar to the starfish, but the central disk is sharply marked off from the arms, and contains all the internal organs responsible for digestion and reproduction. ${ }^{\mathbf{9} 28,29}$ The underside of the disk contains the mouth, with five jaws formed from skeletal plates. The madreporite is located within one of the jaw plates, and not on the upper side of the animal, as it is in starfishes. ${ }^{28,29}$ Writhing movements of the arms, the brittle stars produce locomotion. ${ }^{\mathbf{4 0}}$

The ophiuroids are scavengers or detritivores and small organic particles, small crustaceans and worms are moved into the mouth by the tube feet. The digestive system is confined to the disc and lacks an anus., ${ }^{9,28}$

Brittle stars can easily regenerate lost arms or arm segments unless all arms are lost. Discarded arms have not the ability to regenerate. The ophiuroids use this capacity to escape predators or reproduction. Some brittle stars, such as Ophiactis savignyi and Ophiocomella ophiactoides, exhibit fissiparity with the disk splitting in half. ${ }^{28,41,42}$ In most species the sexual individuals are separate, although a few are hermaphroditic. The gonads are located in the disk, and the gametes are shed into the surrounding water. ${ }^{28,42}$

\section{Bioactive compounds and biological activities}

\subsection{Triterpene glycosides}

The holostan-type triterpene glycosides, identified as marmoratoside A (1), $17 \alpha$-hydroxy impatienside A (2), marmoratoside B, 25acetoxy bivittoside $\mathrm{D}$ were isolated from the sea cucumber Bohadschia marmorata collected from offshore waters of Hainan Island in the South Sea of China. Moderate antifungal activity were observed for (1) and (2). ${ }^{43}$ The sea cucumber Holothuria (Microthele) axiloga sampled from the same regional waters yielded arguside $\mathrm{F}$, impatienside B (3), and pervicoside D. Compound (3) showed antifungal activity. ${ }^{44}$ Bioactive triterpene glycosides, echinoside A (4) and holothurin $\mathrm{A}_{1}(5)$ isolated from Holothuria scabra (also from South China Sea) for the first time, showed antifungal activity. ${ }^{45}$

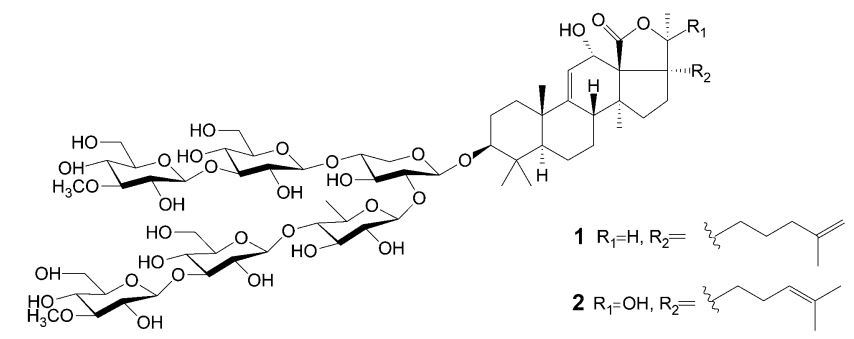

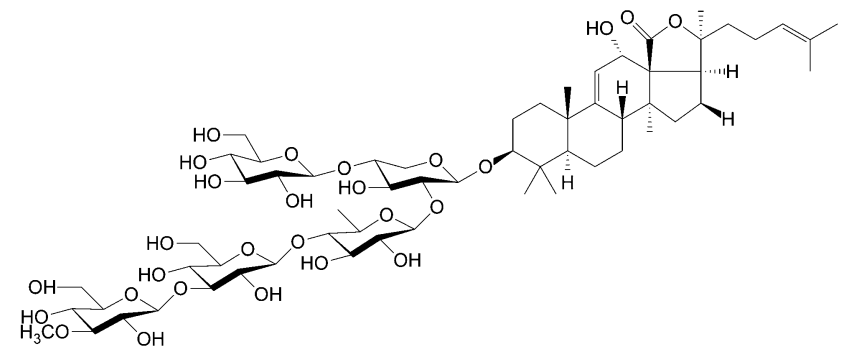

3

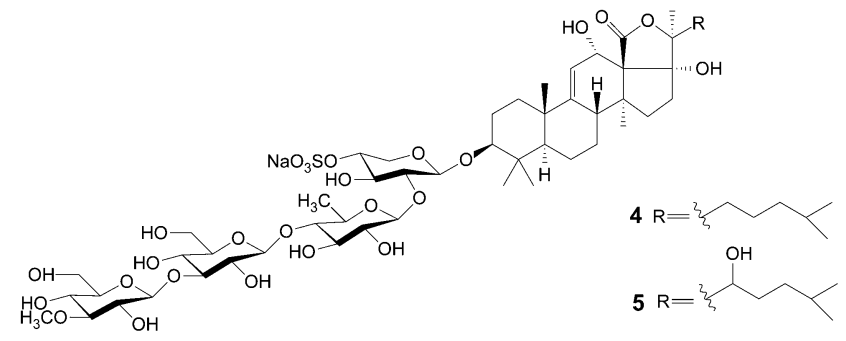

Leucospilotaside $\mathrm{B}(\mathbf{6})$, holothurin $\mathrm{B}_{2}$ and echinoside $\mathrm{B}$ were isolated from the sea cucumber Holothuria leucospilota (again also from South China Sea). Leucospilotaside B is a new triterpene glycoside, and the other compounds have been isolated for the first time from this sea cucumber. ${ }^{45}$ Compound (6) exhibited moderate cytotoxicity against human tumor cell lines (HL-60, MOLT-4, A-549, and BEL-7402). ${ }^{46}$ The glycosides, achlioniceosides $\mathrm{A}_{1}, \mathrm{~A}_{2}$ and $\mathrm{A}_{3}$, (Antarctic sea cucumber Achlionice Violaecuspidata) were the first triterpene glycosides isolated from the sea cucumber belonging to the order Elasipodida, but the bioactivity has not been reported for these compounds. ${ }^{47}$ Two holostanes with a trisaccharide moiety, pentactaside I (7) and II (8), and a disaccharide pentactaside III (9) rarely isolated from sea cucumbers (Pentacta quadrangularis, Zhanjiang, South China Sea) showed in vitro cytotoxicity against tumor cell lines (P-388, A-549, MCF-7, MKN-28, HCT-116, and U87MG). ${ }^{46}$ The isomeric tetrasaccharides, pentactaside B (10) and C (11) (sea cucumber Pentacta quadrangularis, Guangdong Province), showed cytotoxicity against human tumor cell lines (P388, HCT-116, MCF-7, MKN-28, and A-549). ${ }^{48}$ Isolated for the first time from the sea cucumber Apostichopus japonicus (Qingdao Sea, Eastern China) was cladoloside B (12). ${ }^{49}$ Compound (12) showed growth inhibitory antifungal activity against Candida albicans, Cryptococcus neoformans, Candida tropicalis, Trichophyton rubrum, Microsporum gypseum and Aspergillus fumigatus. ${ }^{\mathbf{5}}$

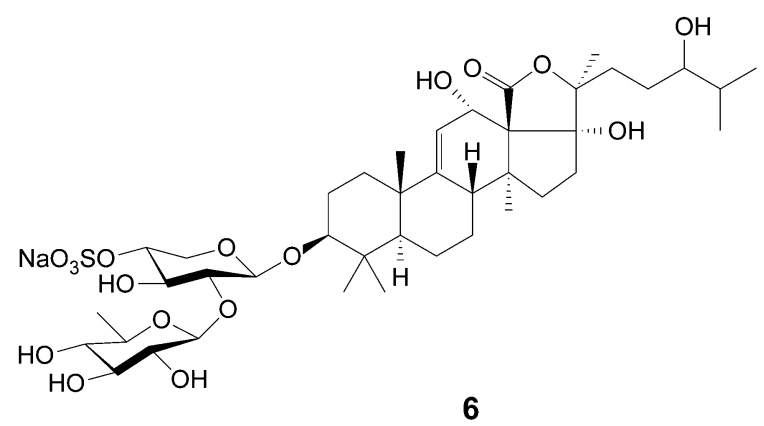



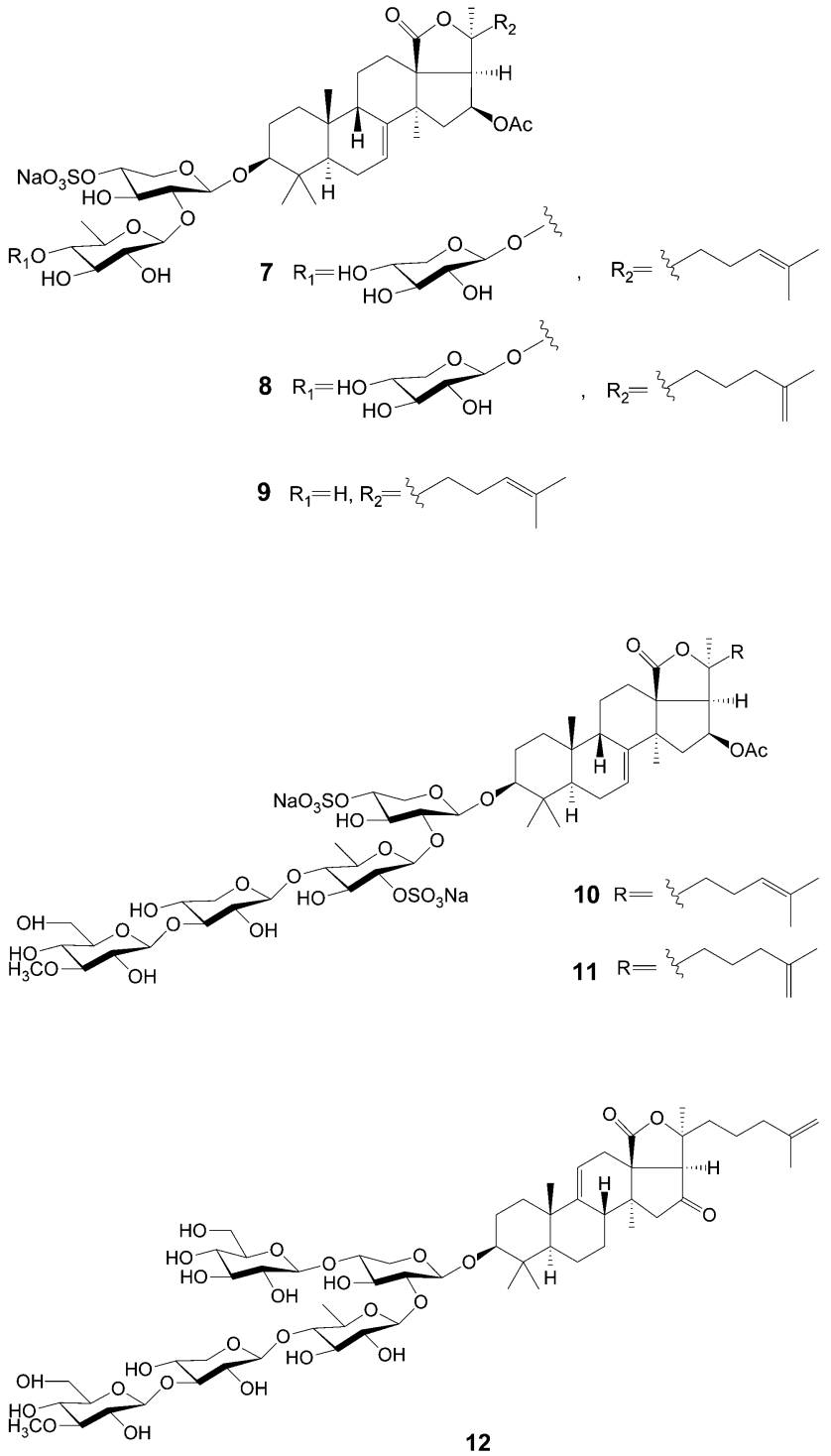

Liouvillosides $\mathrm{A}_{4}$ and $\mathrm{A}_{5}$, two minor triterpene glycosides were isolated from the sea cucumber Staurocucumis liouvillei (Bouvet Island, South Atlantic Ocean). The glycosides $\mathrm{A}_{4}$ and $\mathrm{A}_{5}$ are disulphated tetraosides with a very rare 3-Omethylquinovose as terminal monosaccharide, but their bioactivity has not been reported. ${ }^{51}$ Desulfated echinoside A (13) (sea cucumber Pearsonothuria graeffei, Qingdao, China) inhibited in vitro, the proliferation of human cancer cells (HepG2) and reduced the tube formation of human endothelial cells (ECV-304) whereas in vivo, attenuated the neovascularization in the chick embryo chorioallantoic membrane. Ds-echinoside A (13) also exhibited anti-metastatic activity via inhibition of NF-kBdependent matrix metalloproteinase-9 and vascular endothelial growth factor. ${ }^{52}$ Isolated from the Far Eastern sea cucumber Eupentacta fraudatrix (Troitsa Bay, Sea of Japan), were the cucumariosides $\mathrm{H}_{5}(\mathbf{1 4}), \mathrm{H}_{6}(\mathbf{1 5}), \mathrm{H}_{7}(\mathbf{1 6})$ and $\mathrm{H}_{8}$. Compounds (14-16) were cytotoxic against mouse lymphocytes and hemolytic against mouse erythrocytes. ${ }^{53}$ Two sulfated triterpenes patagonicoside B (17) and C (18) isolated from the sea cucumber Psolus patagonicus (The Bridges Island, Tierra del Fuego, Argentina) exhibited antifungal activity towards Cladosporium cladosporoides..$^{54}$
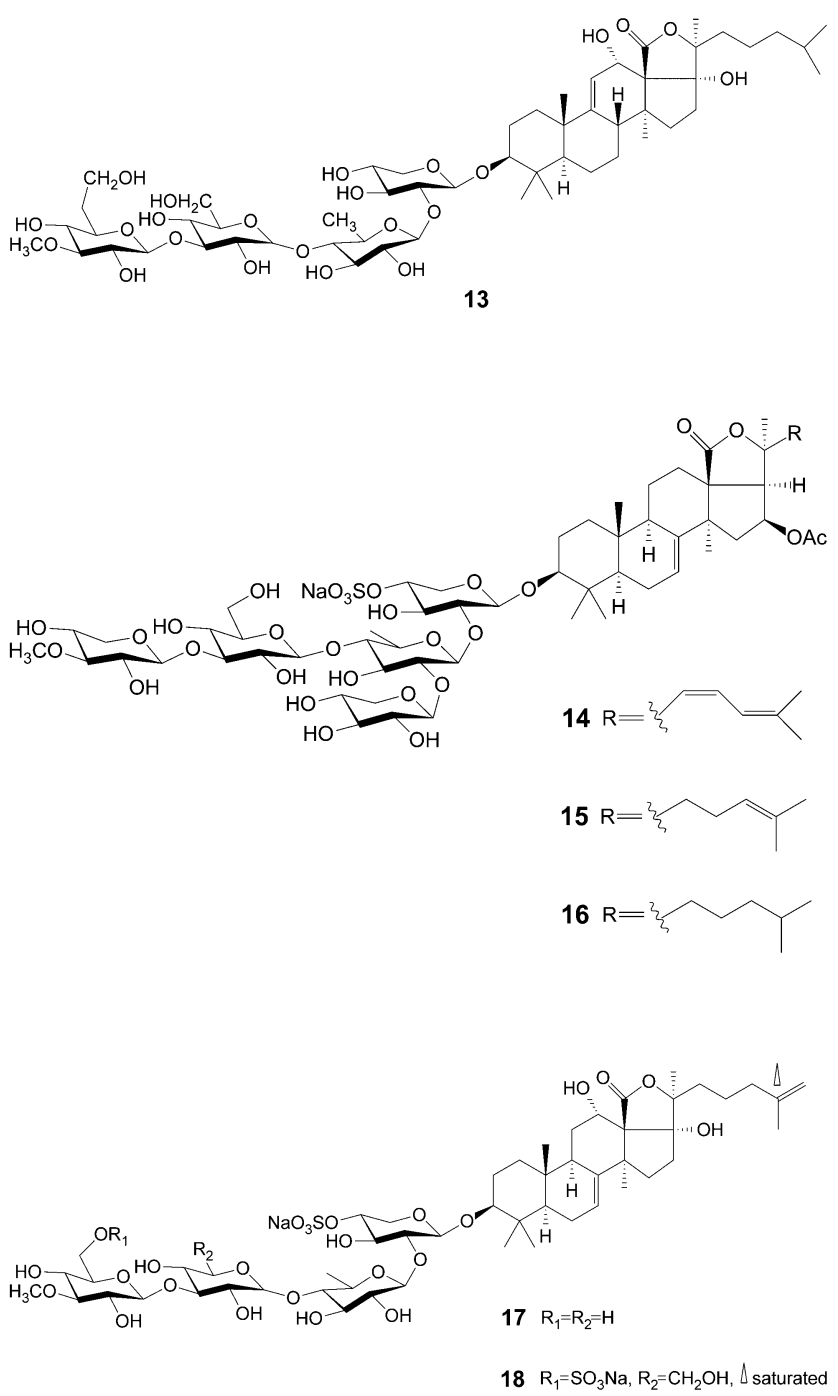

Nobiliside I and nobiliside II, two new triterpene glycosides were isolated from sea cucumber Holothuria nobilis (Fujian, Qingdao Ocean), but their bioactivity has not been reported..$^{55}$ Holotoxin D (19) sea cucumber Apostichopus japonicus (Qingdao Sea, Eastern China) was isolated for the first time by Yuan et $a .^{56}$ and exhibited growth inhibitory antifungal activity against Candida albicans, Cryptococcus neoformans, Candida tropicalis, Trichophyton rubrum, Microsporum gypseum and Aspergillus fumigatus. ${ }^{50}$ A nortriterpene glycoside, 26-nor-25oxo-holotoxin $\mathrm{A}_{1}$ (20), four triterpene glycosides, including both holostane and non-holostane types analogues, holotoxins E (21), F (22) and G (23) (sea cucumber Apostichopus japonicus, Dalian coast, Bohai Sea of China) showed potent antifungal activity. ${ }^{50}$ 

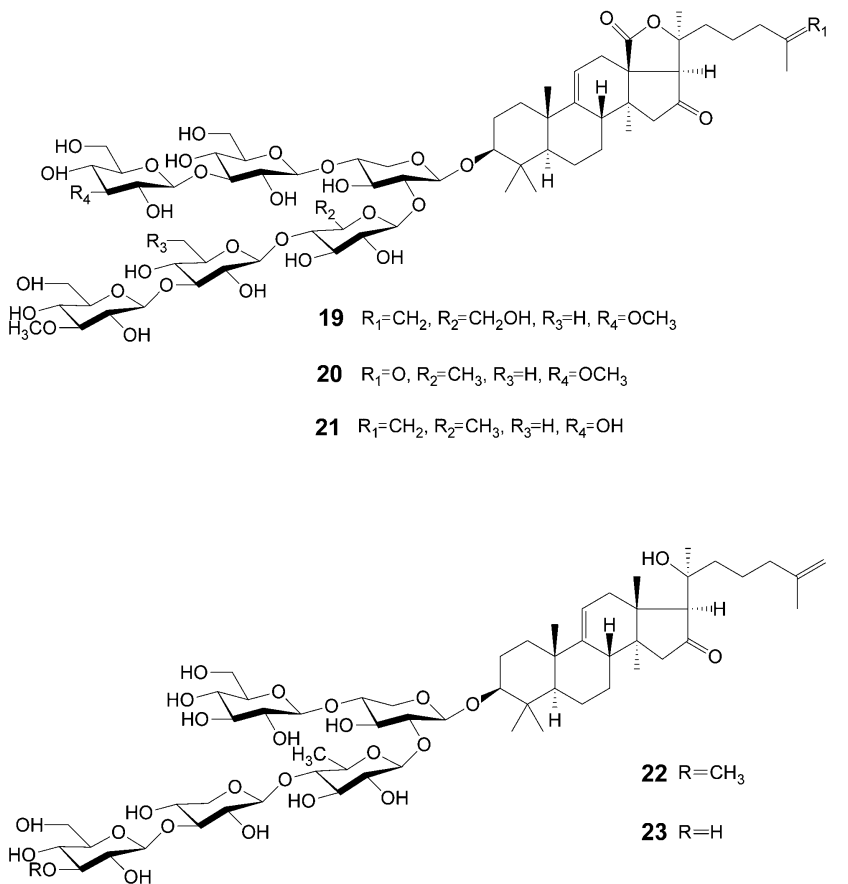

Holostan-type glycosides, holotoxin $\mathrm{D}_{1}(\mathbf{2 4})$ and 25,26dihydroxy-holotoxin $\mathrm{A}_{1}$ (25) (sea cucumber Apostichopus japonicus) exhibited potent antifungal activity. ${ }^{57}$ Minor triterpene glycosides, identified as cucumariosides $\mathrm{A}_{1}(\mathbf{2 6}), \mathrm{A}_{3}$, $\mathrm{A}_{4}, \mathrm{~A}_{5}, \mathrm{~A}_{6}$ (27), $\mathrm{A}_{12}, \mathrm{~A}_{15}$, and cucumarioside $\mathrm{A}_{2}(28), \mathrm{A}_{7}, \mathrm{~A}_{8}$ (29), $A_{9}, A_{10}(30), A_{11}, A_{13}$ (31), $A_{14}, B_{1}, B_{2}$ (32) were isolated from the sea cucumber Eupentacta fraudatrix (Troitsa Bay, Japan Sea). ${ }^{58-61}$ Glycosides (26), (27), (28), (29), (30), and (31) were the most active agents against mouse spleen lymphocytes with cytotoxic action against Ehrlich carcinoma. Compound (32) demonstrated low cytotoxic action against Ehrlich carcinoma. Compounds (26), (27), (28), (30), (31), and (32) showed hemolytic activity against mouse erythrocytes and compounds (26) and (27) antifungal activity. ${ }^{58-61}$

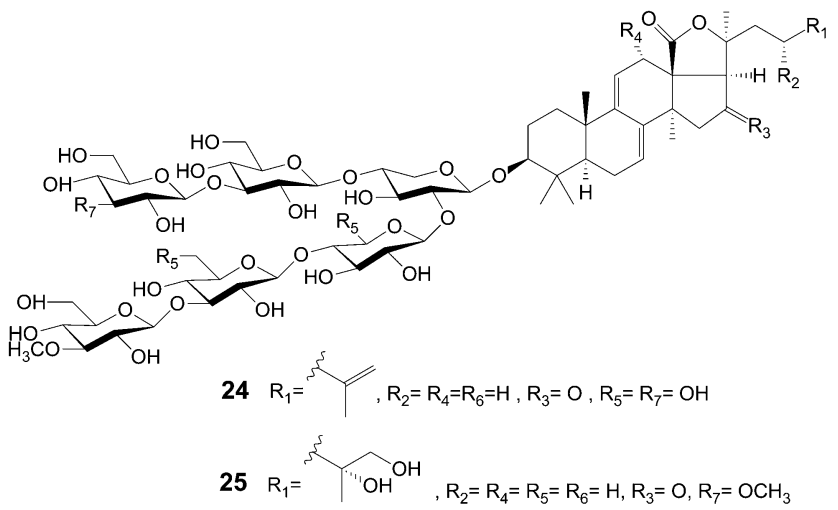

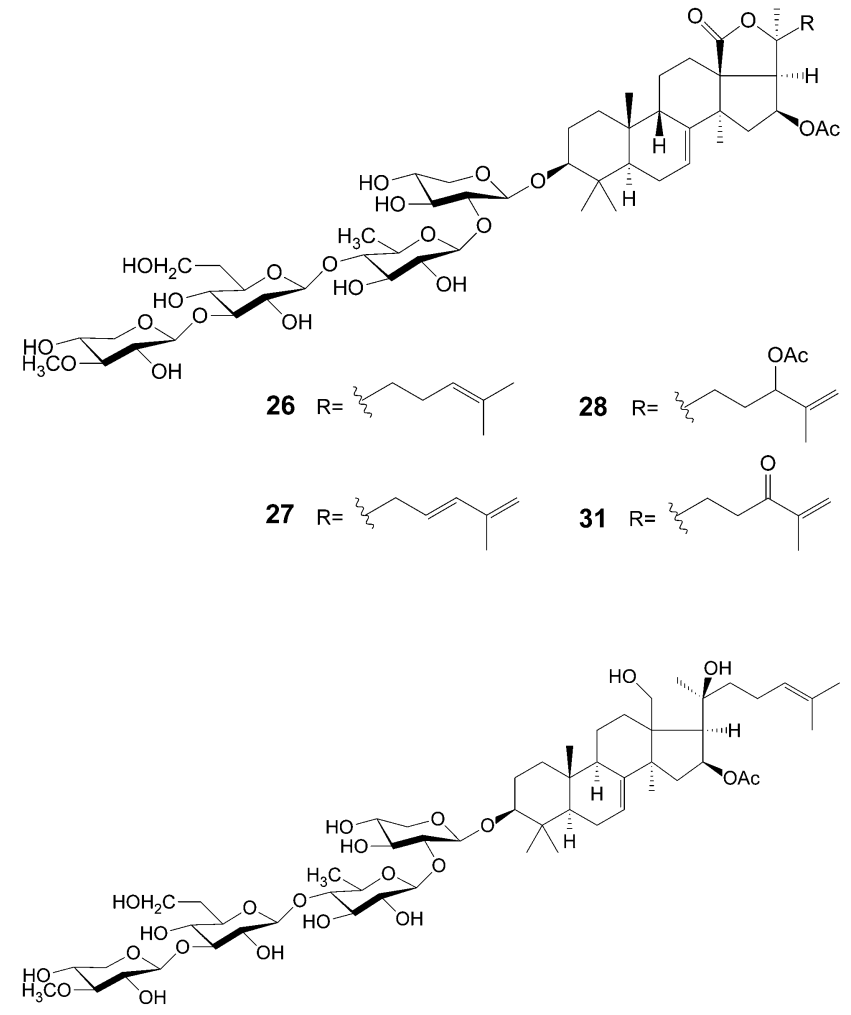

29
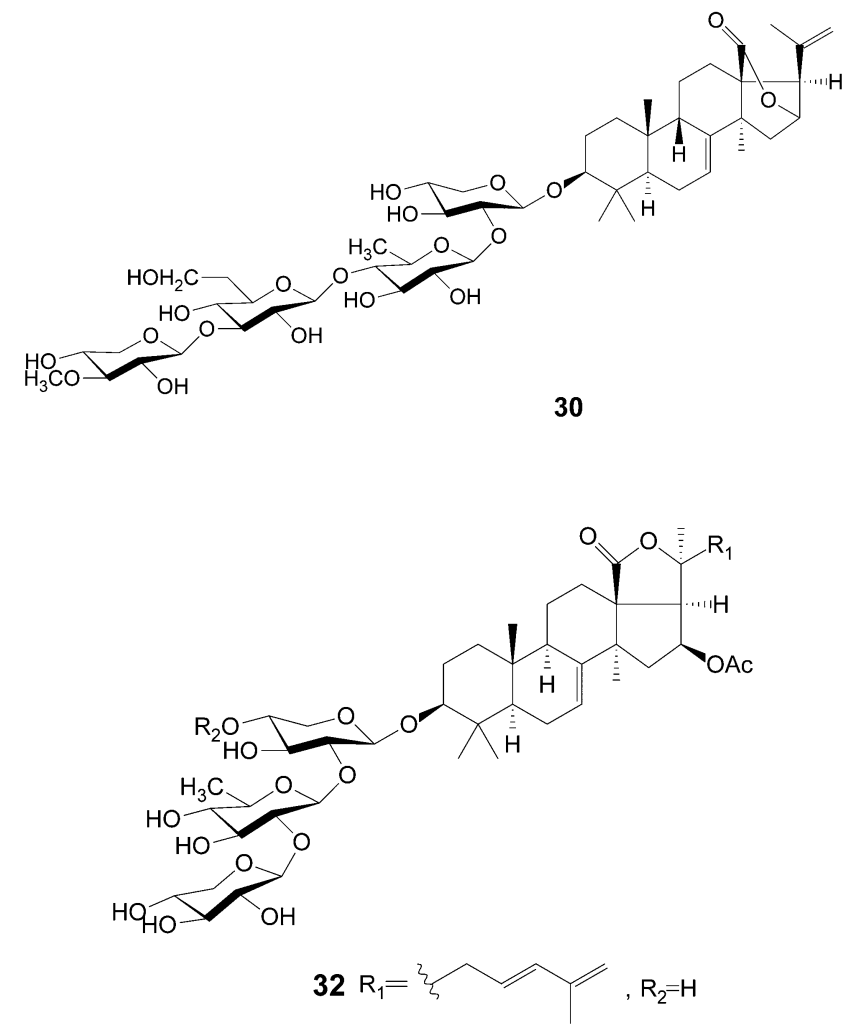

The cucumariosides $\mathrm{H}_{2}, \mathrm{H}_{3}$ and $\mathrm{H}_{4}$ (33) were isolated from the same invertebrate and collected from the same area in the 
Japan Sea. Compound (33) with a 25-ethoxy group showed potent cytotoxic activity against lymphocytes and very high hemolytic activity. ${ }^{62}$ Isolation of echinosides A (34) and B (35) from the sea cucumber Holothuria polii (Red Sea, Egypt) was reported for the first time by Melek et al. ${ }^{63}$ Compounds (34) and (35) possess potential in vitro schistosomicidal activity against Schistosoma mansoni adult worms. ${ }^{63}$ Scabraside D (36), fuscocineroside C (37) and 24dehydroechinoside A (38) were isolated from Holothuria scabra for the first time by Han et al. ${ }^{64}$ The glycosides (36-38) showed in vitro cytotoxicity against human tumor cell lines (P-388, A-549, MKN-28, HCT-116, and MCF-7). ${ }^{64}$ Pseudocnoside A (39) (sea cucumber Pseudocnus dubiosus leoninus, South Atlantic Ocean), showed cytotoxicity and antiproliferative activity against cancer cell lines (A-549 and HeLa). ${ }^{65}$
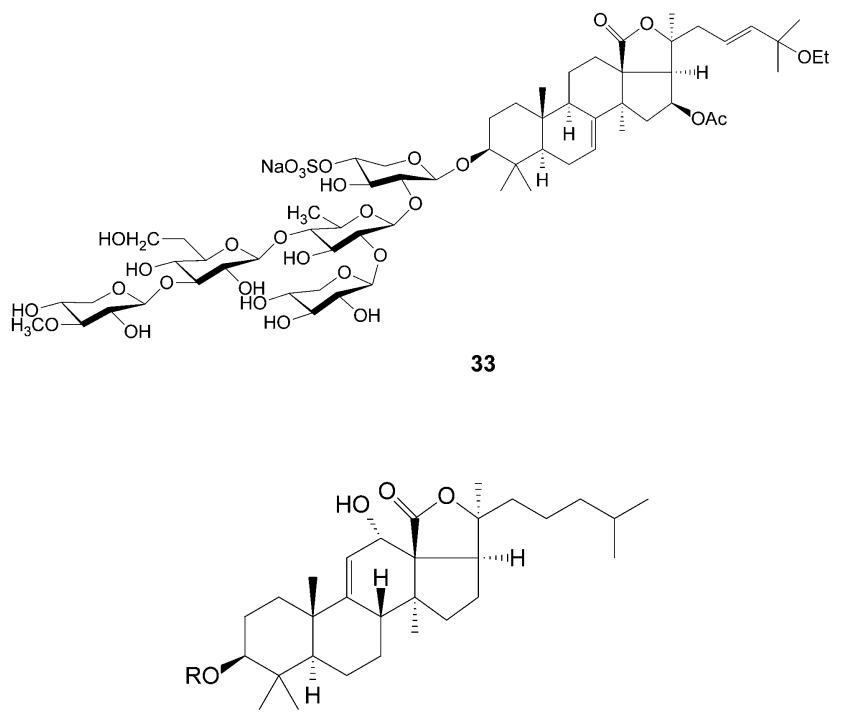

$34 \mathrm{R}=3-\mathrm{O}-$-methyl- $\beta$-D-glucopyranosyl-( $(1 \rightarrow 3)-\beta$-D-glucopyranosyl$(1 \rightarrow 4)-\beta$-D-qinovopyranosyl-(1 $\rightarrow 2)-4-O-$-sodiosulphato- $\beta$-D-xylopyranosyl

$35 \mathrm{R}=\beta$-D-quinovopyranosyl-(1 $\rightarrow 2)-4-\mathrm{O}-$-sodiosulphato- $\beta$-D-xylopyranosyl

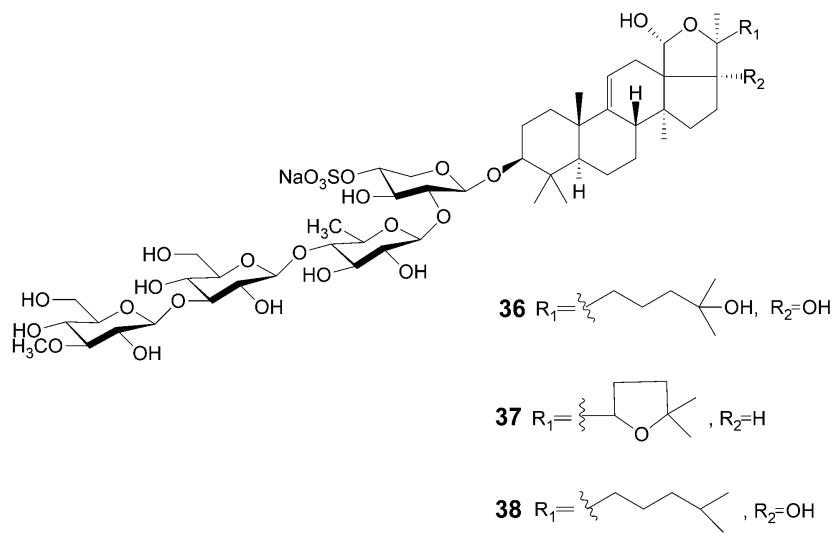

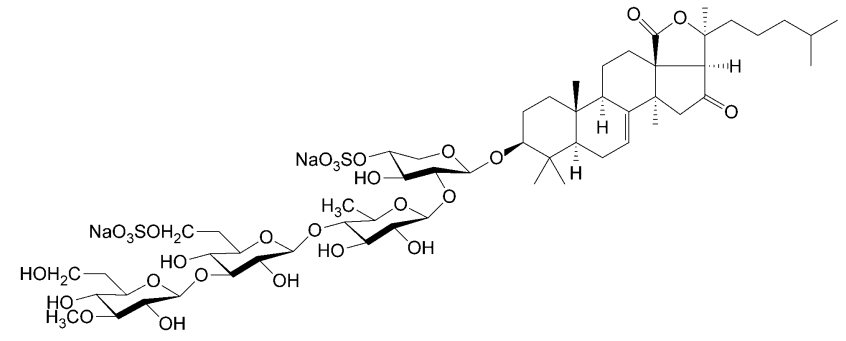

39

A new triterpene holostane disulfated tetrasaccharide olygoglycoside, turquetoside A, containing a rare terminal 3$O$-methyl-D-quinovose was isolated from the sea cucumber Staurocucumis turqueti (Eastern Weddell Sea, Antarctic), but its bioactivity has not been reported ${ }^{66}$ Cucumarioside $\mathrm{I}_{2}(\mathbf{4 0})$ isolated from the sea cucumber Eupentacta fraudatrix (Troitsa Bay, Japan Sea) increased the lysosomal activity of macrophages. ${ }^{67}$ Cucumariosides $\mathrm{I}_{1}(\mathbf{4 1}), \mathrm{I}_{3}$ and $\mathrm{I}_{4}$ also were isolated from the sea cucumber Eupentacta fraudatrix (Troitsa Bay, Japan Sea). Compound (41) showed cytotoxicity against mouse spleen lymphocytes and Ehrlich carcinoma as well as cytotoxicity, hemolytic activity against mouse erythrocytes and antifungal activity. ${ }^{68} \mathrm{~A}$ minor triterpene glycosides, typicosides $A_{1}(42), A_{2}(43), B_{1}(44), C_{1}$ and $C_{2}(45)$ were isolated from the sea cucumber Actinocucumis typical. The new glycosides (42-45), contained a hydroxyl-group in the aglycone side chain, demonstrating rather strong hemolytic and cytotoxic activities. ${ }^{69}$
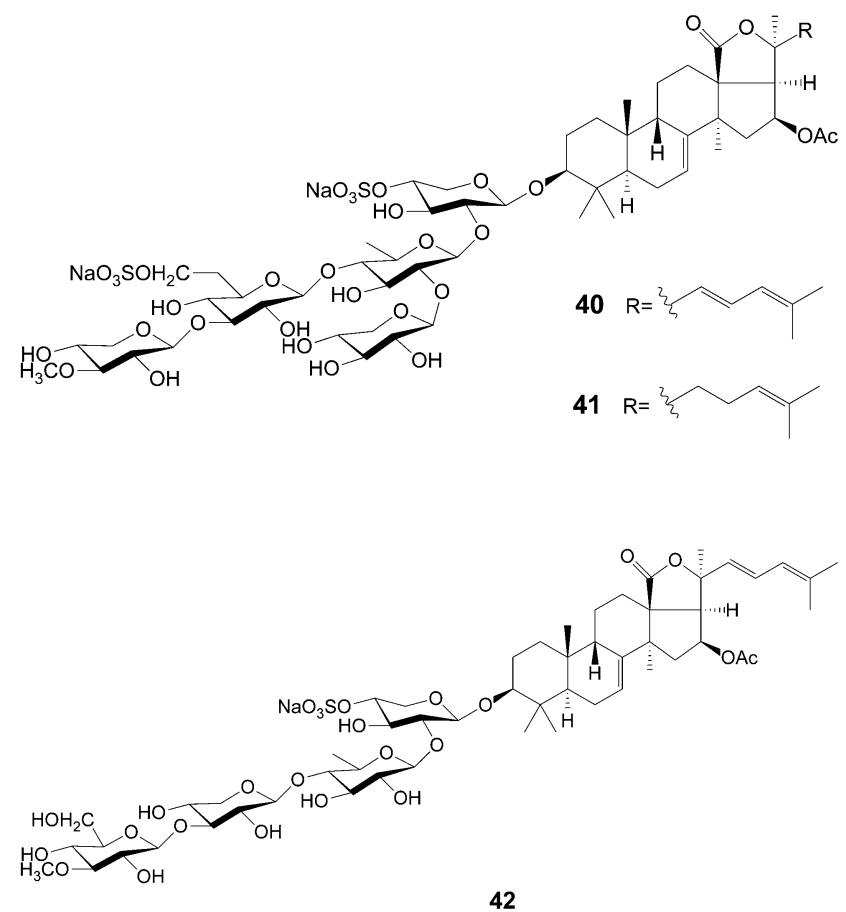


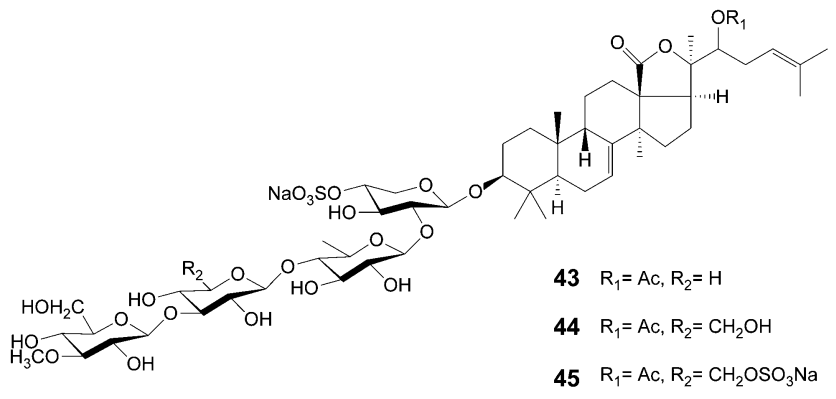

Sea cucumber Cladolabes schmeltzii (tropical Indo-West Pacific Sea) yielded cladolosides B1, B2, C, C1, C2 and D (46-51) with strong cytotoxic and hemolytic effects. ${ }^{70}$
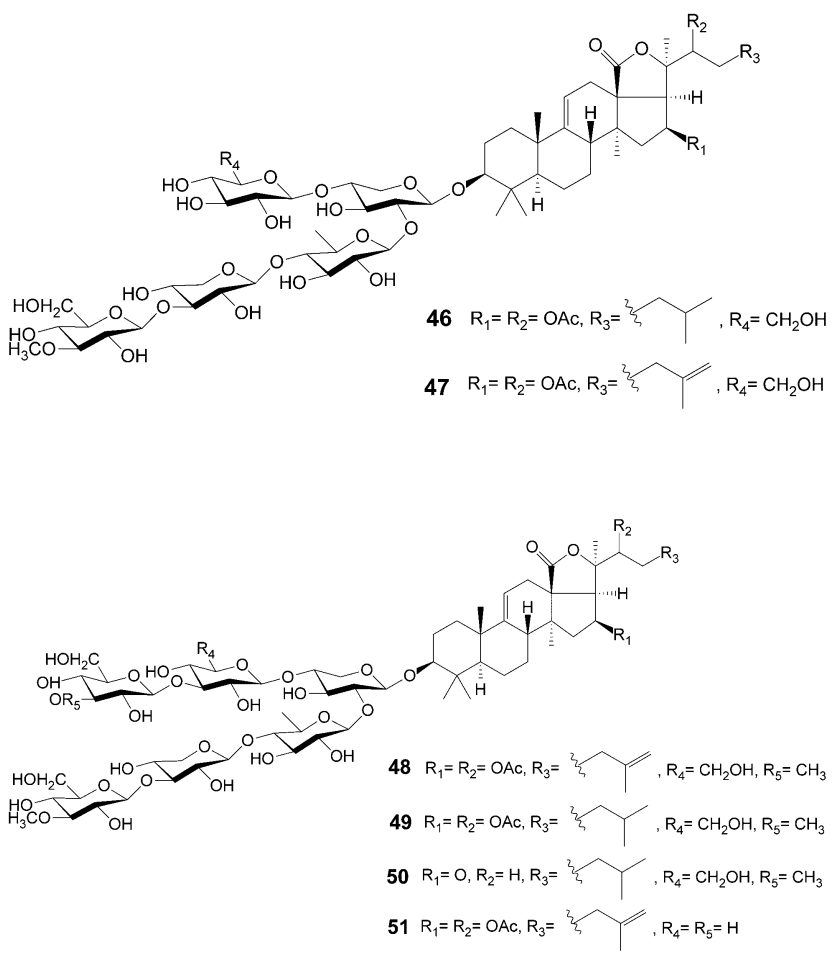

\subsection{Steroids}

Steroid glycosides, such as evasterioside C was isolated from starfish Evasterias retifera (Sea of Japan), and evasteriosides D (52) and E from Evasterias echinosoma (Gulf of Shelichov, Okhotsk Sea). ${ }^{71}$ Compound (52) stimulated p53 activity. Evasterioside $\mathrm{C}$ and $\mathrm{E}$ showed no p53 activity. ${ }^{72}$ Steroidal monoglycosides, kurilensosides E, F, G, H (53-56) and 15-Osulfate of echinasteroside $C$ (57) were isolated from the Far Eastern starfish Hippasteria kurilensis (Kuril Islands) and inhibited the egg fertilization by sperm of the sea urchin Strongylocentrotus nudus. Kurilensoside $\mathrm{H}$ that contains 4,5-epoxy functionality was the 15-sulfate analogue of the co-metabolite echinastero echinasteroside C. ${ }^{73}$ Kurilensoside I and kurilensoside J isolated from the Far East starfish Hippasteria kurilensis (Sea of Okhotsk) have a 2-Omethyl- $\beta$-D-xylopy-ranose residue at C3 of polyhydroxylated steroid aglycone, but the bioactivity has not been reported for these compounds. ${ }^{74}$ Anthenoside A (58) (starfish
Anthenea chinensis; Sanya Bay, South China Sea) exhibited cytotoxicity against human tumor cell lines (HL-60, MOLT-4, A-549 and BEL-7402) and promoted tubulin polymerization. $^{75}$

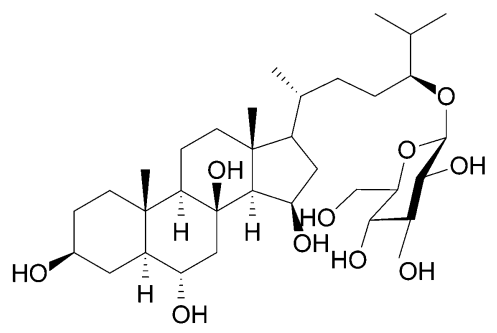

52

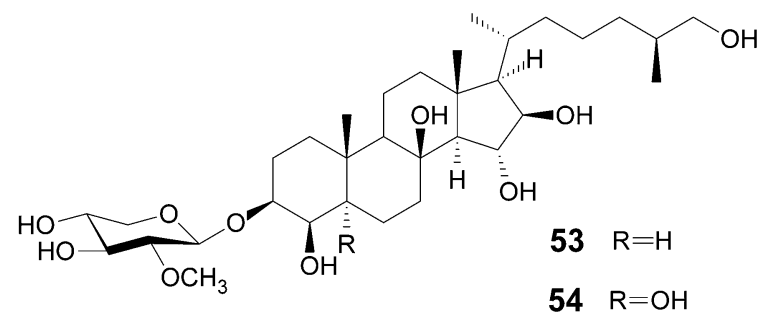

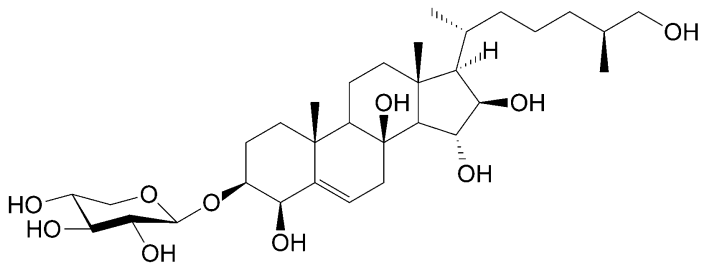

55

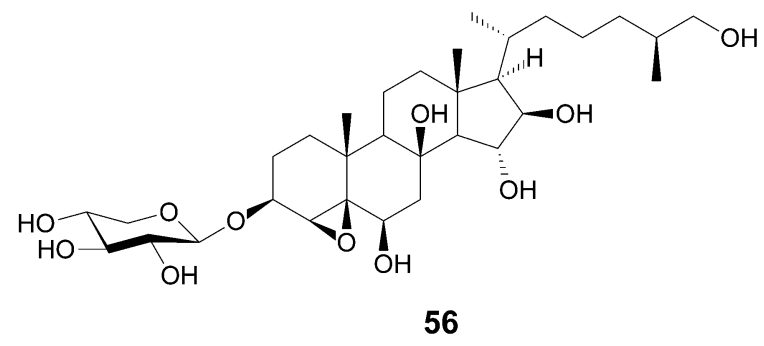

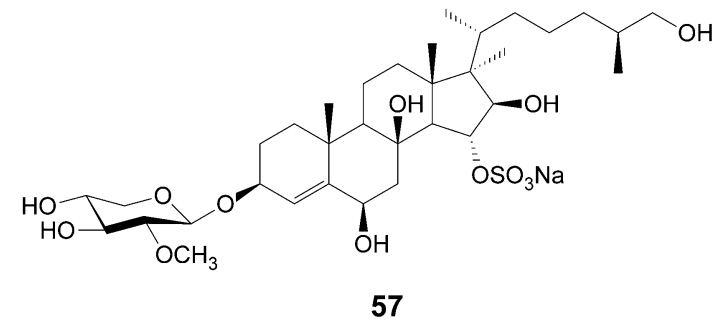




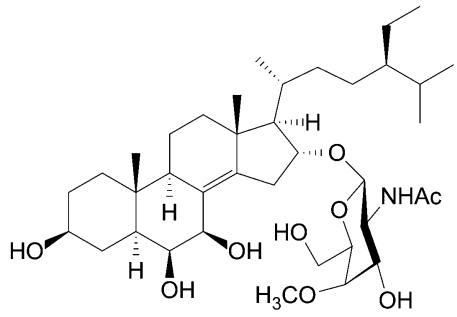

58

Isolated from the starfish Archaster typicus, (Quang Ninh, Vietnam) was the polyhydroxysteroid, named (24R)-27-nor-5 $\alpha$ cholestane-3 $\beta, 6 \alpha, 8,14,15 \alpha, 24$-hexaol, although the bioactivity has not been reported. ${ }^{76}$ Sterol sulfates lysaketotriol (59) and lysaketodiol (60) (starfish Lysastrosoma anthosticta; Sea of Japan) showed immunomodulatory activity. Compound (59) produced moderate stimulation of lysosomal activity in mouse splenocytes. ${ }^{77}$ The glycoside, identified as $1-O-(\beta$-D-quinovopyr-anosyl$(1 \rightarrow 2)$ - $\beta$-D-fucopyranosyl- $(1 \rightarrow 4)$-[ $\beta$-D-fucopyranosyl- $(1 \rightarrow 2)]-\beta$-Dquinovopyranosyl)-butanol (61) (starfish Asterias amurensis; Guangxi, North Sea of China) promotes osteoblastic proliferation. ${ }^{78}$ A new glycoside, typicusoside A (62), and four highly hydroxylated steroids, named (24R)-27-nor-5 $\alpha$-cholestane$3 \beta, 4 \beta, 6 \alpha, 8,14,15 \alpha, 24$-heptaol (63), $5 \alpha$-cholestane$3 \beta, 4 \beta, 5,6 \alpha, 8,14,15 \alpha, 24,26$-nonaol (64), $5 \alpha$-cholest-25-(27)-ene$3 \beta, 6 \alpha, 8,14,15 \alpha, 24,26$-heptaol 15-O-sulfate, sodium salt (65), and (23E)-27-nor-25-oxo-5 $\alpha$-cholest-23-ene-3 $\beta, 6 \alpha, 8,14,15 \alpha$-pentaol 15-O-sulfate, sodium salt (66) (starfish Archaster typicus; coast-<smiles>[R]CC(=O)C[C@@H](C)[C@H]1CC[C@H]2[C@@H]3C[C@H](O)[C@@H]4C[C@@H](OS(C)(=O)=O)CC[C@]4(C)[C@H]3CC[C@]21C</smiles>

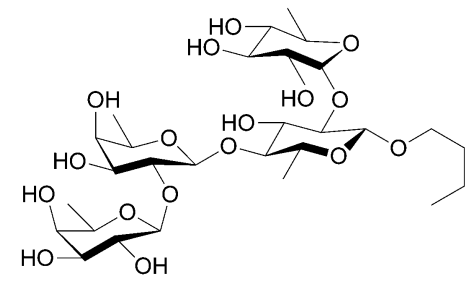

61

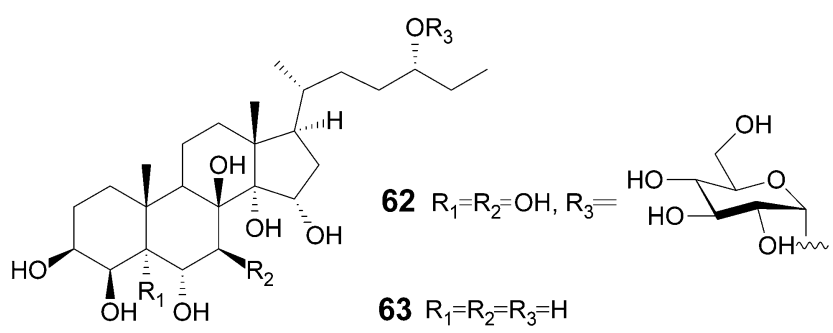

line of Quang Ninh, Vietnam) revealed moderate toxic effects in the sperm and blastomere on embryonal development of the sea urchin Strongylocentrotus intermedius. ${ }^{79}$ The starfish Solaster endeca (Okhotsk Sea, Shelikhov Gulf), yielded a (20R)-5 $\alpha$-cholestan-3 $\beta, 6 \alpha, 8,15 \alpha, 24,26$-hexaol (67), which caused an increase of $30 \%$ in the lysosomal activity. ${ }^{72}$

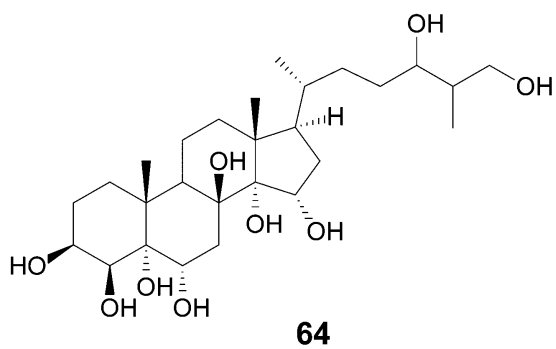

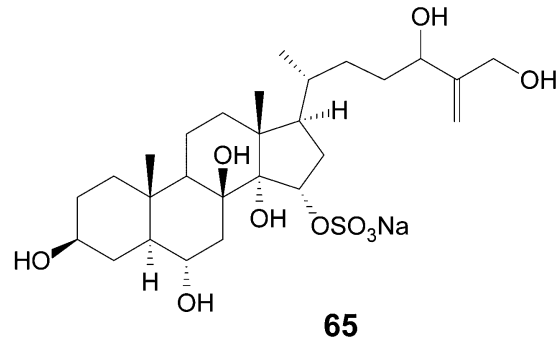

65

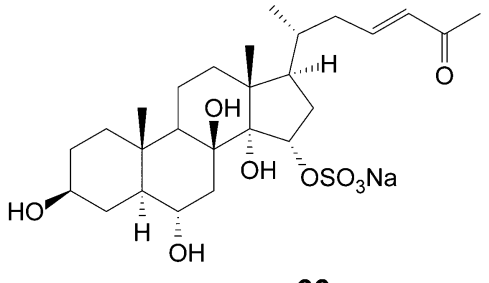

66

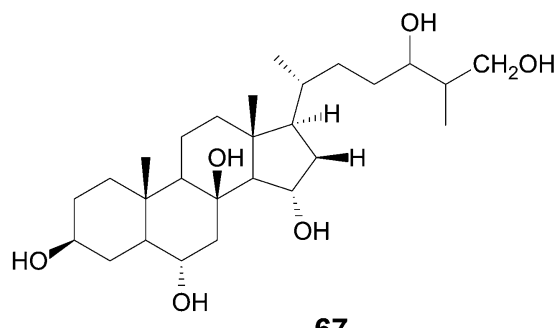

67

A new pentasaccharide, named hylodoside A (68), was isolated from the starfish Leptasterias hylodes (Okhotsk Sea), while disaccharide novaeguinoside Y (69) was isolated from Culcita novaeguineae (Seychelles). Steroids (68) and (69) showed moderate hemolytic activity in the mouse erythrocytes assay. ${ }^{\mathbf{8 0}}$ The anthenosides B, C, D, E (70), F, G (71), H (72), I (73), J (74) and $\mathrm{K}$ (75) are polyhydroxysteroidal glycosides (starfish Anthenea chinensis; Sanya Bay, South China Sea). Compounds (70), (71), a mixture of (72) and (73) as well as a mixture of (74) and (75) showed inhibitory activity against human tumor cells (K- 
562 and BEL-7402). The mixture of (74) and (75) also exhibited cytotoxicity against human tumor U87MG cells and promoted tubulin polymerization. ${ }^{81}$ The $(24 R, 25 S)$-24-methyl-5 $\alpha$-cholestane-3 $\beta, 6 \alpha, 8,15 \beta, 16 \beta, 26$-hexaol; $\quad(22 E, 24 R, 25 S)$-24-methyl-5 $\alpha$ holest-22-ene-3 $\beta, 6 \alpha, 8,15 \beta, 16 \beta, 26$-hexaol; and $(22 E, 24 R, 25 S)$-24methyl-5 $\alpha$-cholest-22-ene-3 $\beta, 4 \beta, 6 \alpha, 8,15 \beta, 16 \beta, 26$-heptaol were isolated from the starfish Asteropsis carinifera (Van Fong Bay, Vietnam), but the bioactivity has not been reported for these compounds. ${ }^{82}$ A new polyhydroxy sterol ester, (25S)-5 $\alpha$-cholestane-3 $\beta, 6 \alpha, 7 \alpha, 8,15 \alpha, 16 \beta$-hexahydroxyl-26-O-14' $Z$-eico-senoate, isolated from the starfish Asterina pectinifera (Liaoning province, China) do not showed antiviral activity against herpes simplex virus type 1 or cytotoxicity against human liver carcinoma HepG2 cell line in vitro. ${ }^{83}$

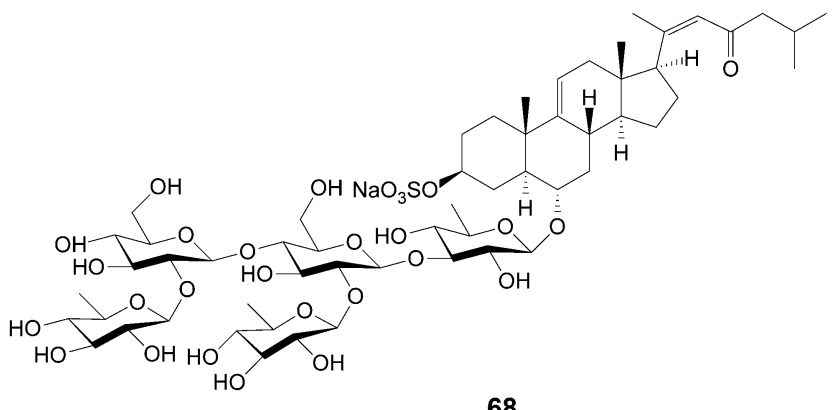

68

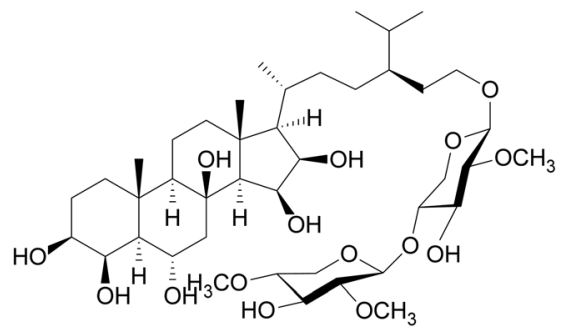

69

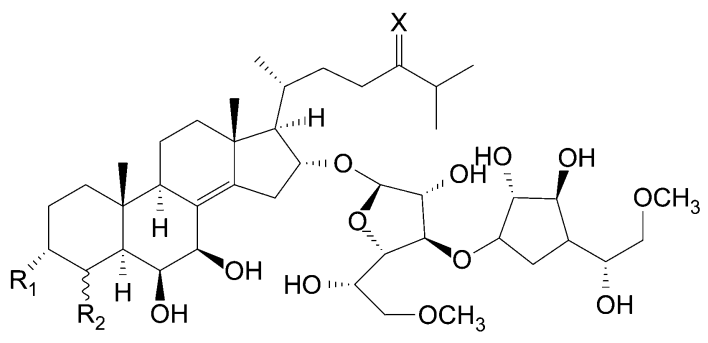

$70 \mathrm{R}_{1}=\mathrm{OH}, \mathrm{R}_{2}=\mathrm{H}, \mathrm{X}=2 \mathrm{H}$

$71 \mathrm{R}_{1}=\mathrm{OH}, \mathrm{R}_{2}=\mathrm{H}, \mathrm{X}=\mathrm{CH}_{2}$

The starfish Archaster typicus (Qingping Market, Guangzhou, China), yielded sodium $5 \alpha$-cholesta-9(11),24-dien-3 $\beta, 6 \alpha, 20 \beta$ triol-23-one 3-sulphate (76), sodium 5 $\alpha$-cholesta-9(11)-en$3 \beta, 6 \alpha, 20 \beta$-triol-23-one 3 -sulphate; sodium (25R)-5 $\alpha$-cholestane$3 \beta, 4 \beta, 6 \alpha, 8,14 \alpha, 15 \beta, 26$-heptaol-15-sulphate; sodium (25R)-5 $\alpha$ cholestane-3 $\beta, 6 \alpha, 8,14 \alpha, 15 \beta, 26$-hexaol 15-sulphate; and sodium

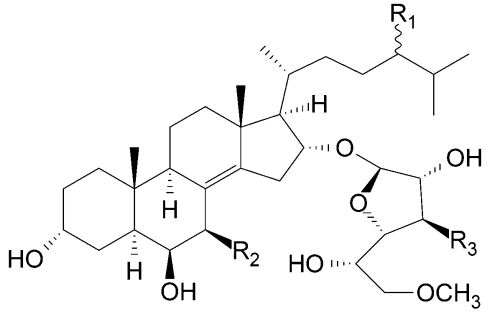<smiles>[R7]C=[R]O</smiles>

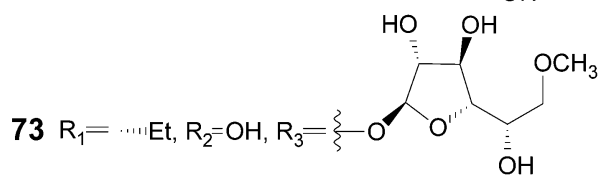

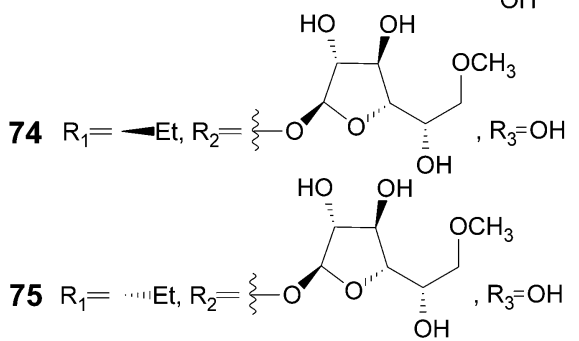

cholest-25(27)-ene-3 $\beta, 4 \beta, 5 \alpha, 6 \alpha, 7 \beta, 8 \beta, 14 \alpha, 15 \alpha, 24,26$-decanol 6sulphate. Steroid (76) exhibited weak anticancer activity (MDAMB-435 and Colo205). ${ }^{84}$ Cariniferosides A, B, C, D, E and F (77), six steroidal biglycosides were isolated from the starfish Asteropsis carinifera (Van Phong Bay, South China Sea). Sulfated compound (77) demonstrated a significant inhibition of cells

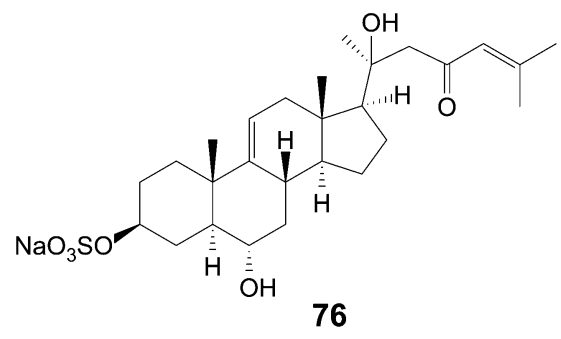

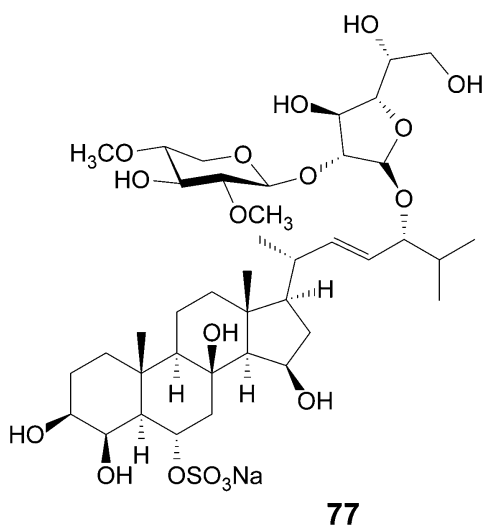


colony formation (RPMI-7951 and T-47D) in a clonogenic assay. ${ }^{85}$ A new steroidal glycoside, called fisherioside A was isolated from the starfish Leptasterias fisheri (Sakhalin Island, Okhotsk Sea). The bioactivity has not been studied. ${ }^{86}$ Starfish Mithrodia clavigera (Maldive islands, Pacific Ocean), yielded a sulfated polyoxide steroid, named mithrotriol. Mithrotriol did not demonstrate cytotoxic effects against human melanoma cell lines. ${ }^{87}$

Steroidal glycosides, identified as pectiniosides $\mathrm{H}-\mathrm{J}$ were isolated from the alcoholic extract of the starfish Asterina pectinifera (Yellow Sea, China), and did not show cytostatic activity on HL-60 cells. ${ }^{68}$ The isolation from the starfish Aphelasterias japonica (Poset Bay, Japan Sea), yielded the aphelasteroside E. The bioactivity has not been studied. ${ }^{\mathbf{8}}$ The neuritogenic and neuroprotective activities of six new starfish polar steroids, (25S)-5 $\alpha$-cholestane-3 $\beta, 4 \beta, 6 \alpha, 7 \alpha, 8,15 \alpha, 16 \beta, 26$-octaol (78), and (25S)-5 $\alpha$-cholestane-3 $\beta, 6 \alpha, 7 \alpha, 8,15 \alpha, 16 \beta, 26$-heptaol (79) from the starfish Patiria pectinifera (Northwestern Pacific Sea) were observed using the mouse neuroblastoma C-1300 cell line and an organotypic rat hippocampal slice culture. ${ }^{89}$

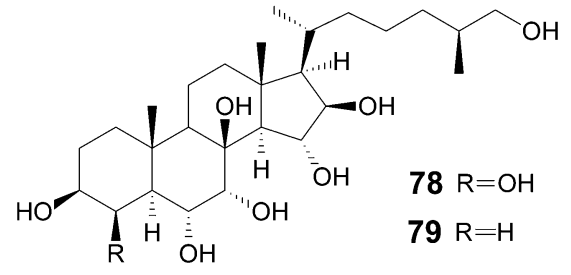

\subsection{Saponins}

Saponins, named holothurinosides E, F, G, H, I, $\mathrm{A}_{1}, \mathrm{C}_{1}, \mathrm{E}_{1}, \mathrm{~F}_{1}$, $\mathrm{G}_{1}, \mathrm{H}_{1}$ and $\mathrm{I}_{1}$ and desholothurin $\mathrm{A}_{1}$ were isolated from the sea cucumber Holothuria forskali collected from offshore waters of Banyuls-sur-Mer in the France, but the bioactivity has not been reported for these compounds. ${ }^{\mathbf{9 0}}$ Isolated from the sea cucumber Holothuria nobilis (Fujian Province, East China Sea)

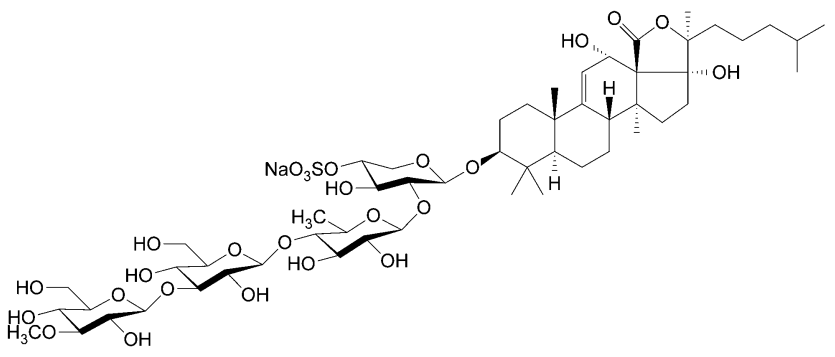

80 was the saponin echinoside A (80), which inhibited the growth of tumors in mouse models as well as human prostate carcinoma xenografts in nude mouse models and inhibited the noncovalent binding of topoisomerase $2 \alpha$ to deoxyribonucleic acid (DNA). ${ }^{91}$ Holothurinoside $\mathrm{J}_{1}(\mathbf{8 1})$ and Holothurinoside $\mathrm{K}_{1}$ (82) were saponins detected in the body wall of sea cucumber Bohadschia subrubra (Great Reef of Toliara, Indian Ocean) and exhibited weak hemolytic activity and orcinol reaction. ${ }^{92}$

Novaeguinosides A-D (83-86) are asterosaponins (starfish Culcita novaeguineae; Sanya Bay, South China Sea) with cytotoxicity against human tumor cell lines (K-562 and BEL-7402). ${ }^{93}$ Two 24-hydroxylated asterosaponins, identified as sodium $(20 R, 24 S)-6 \alpha-O$-(4-O-sodiumsulfato- $\beta$-D-quinovopyranosyl)-5 $\alpha$ cholest-9(11)-en-3 $\beta, 24$-diol 3-sulfate (87) and sodium $(20 R, 24 S)$ $6 \alpha$-O-[3-O-methyl- $\beta$-D-quinovopyranosyl- $(1 \rightarrow 2)-\beta$-D-xylopyranosyl$(1 \rightarrow 3)$ - $\beta$-D-glucopyranosyl]-5 $\alpha$-cholest-9(11)-en-3 $\beta, 24$-diol 3 sulfate (88) (Culcita novaeguineae; South China Sea), showed cytotoxicity against human cell lines (K-562 and BEL-7402) and inactivated tubulin-polymerization. ${ }^{94}$

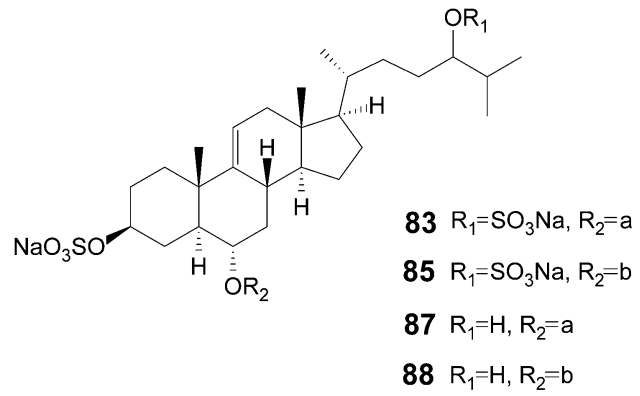

Isolated from the starfish Archaster typicus (Quang Ninh, Vietnam) were the archasterosides A (89), B (90) and C. Compounds (89) and (90) showed moderate cytotoxic activity against cancer cell lines (HeLa and mouse JB6 $\mathrm{P}^{+}$Cl41). ${ }^{95,96}$ Diplasteriosides A (91) and B (92) (starfish Diplasterias brucei; coast of the Ross Sea, Terra Nova Bay, Antarctica) showed toxicity activity against human cell cancer (T47D, RPMI-7951). ${ }^{97}$ In HCT-116 cells, only compound (91) was toxic. ${ }^{98}$ Isolated from starfish Asterias amurensis (Pohang, Korea) were the asterosaponins, named $6 \alpha$-O-[ $\beta$-D-fucopyranosyl- $(1 \rightarrow 2)-\beta$-D-galactopyranosyl-( $1 \rightarrow 4)$-[ $\beta$-D-quinovopyranosyl- $(1 \rightarrow 2)]$ - $\beta$-D-quinovopyranosyl-( $1 \rightarrow 3)$ - $\beta$-D-galactopyranosyl]-5 $\alpha$-chol-9(11)-en-23one-3 $\beta$-yl sodium sulfate $(\mathbf{9 3}), 6 \alpha-O$-[ $\beta$-D-fucopyranosyl- $(1 \rightarrow 2)-\beta$ D-galactopyranosyl- $(1 \rightarrow 4)$-[ $\beta$-D-quinovopyranosyl- $(1 \rightarrow 2)]-\beta$ D-quinovopyranosyl-( $1 \rightarrow 3)$ - $\beta$-D-galactopyranosyl]-5 $\alpha$-cholesta-

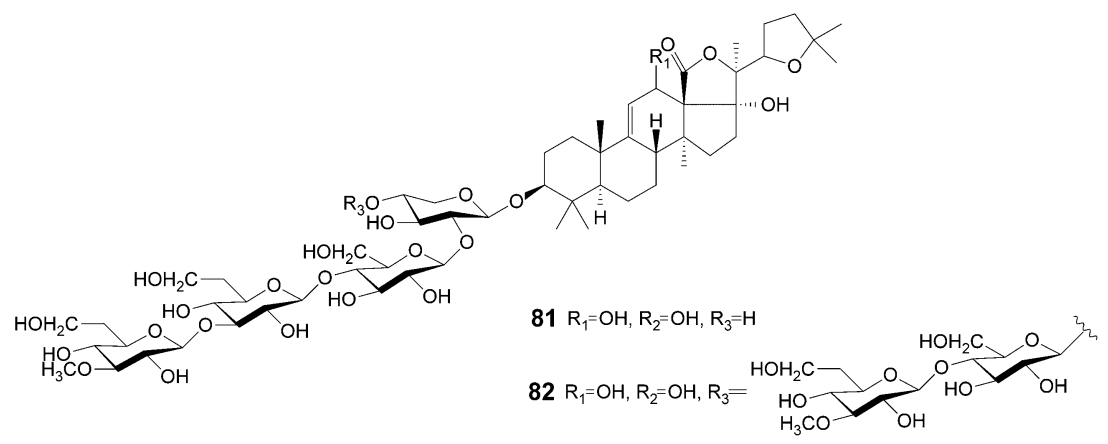


9(11),24-dien-23-one-3 $\beta$-yl sodium sulfate (94), and $6 \alpha-O$-[ $\beta$-Dfucopyranosyl-( $1 \rightarrow 2)$ - $\beta$-D-galactopyranosyl- $(1 \rightarrow 4)$-[ $\beta$-D-quinovopyranosyl- $(1 \rightarrow 2)]$ - $\beta$-D-quinovopyranosyl- $(1 \rightarrow 3)-\beta$-D-galactopyranosyl]-5 $\alpha$-cholest-9(11)-en-23-one-3 $\beta$-yl sodium sulfate (95). Compounds (93-95) revealed cytotoxic effects on to the RAW 264.7 cells. $^{99}$
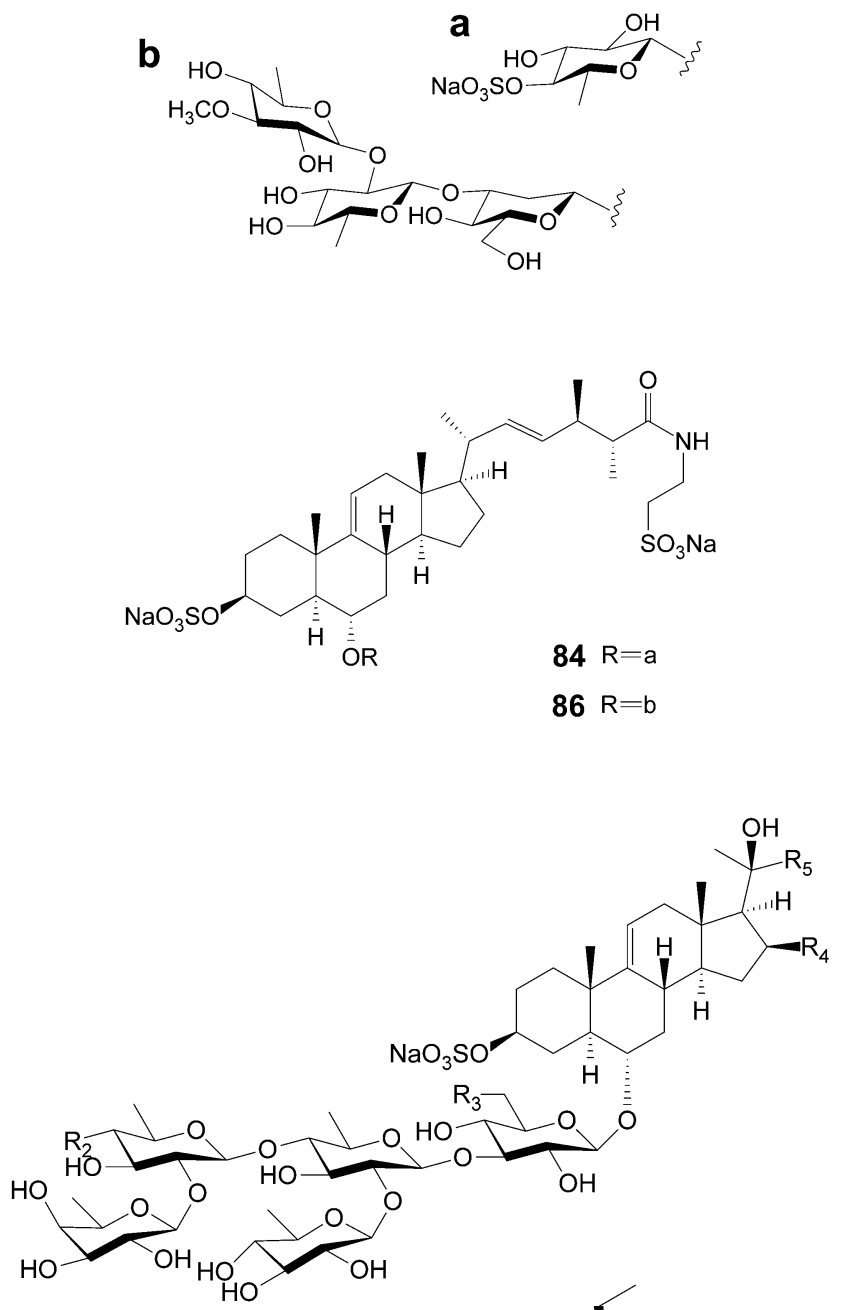

$90 \mathrm{R}_{1}=\mathrm{R}_{4}=\mathrm{H}, \mathrm{R}_{2}=\mathrm{R}_{3}=\mathrm{OH}, \mathrm{R}_{5}=\mathrm{R}_{3}=\mathrm{H}, \mathrm{R}_{2}=\mathrm{R}_{4}=\mathrm{OH}, \mathrm{R}_{5}=$

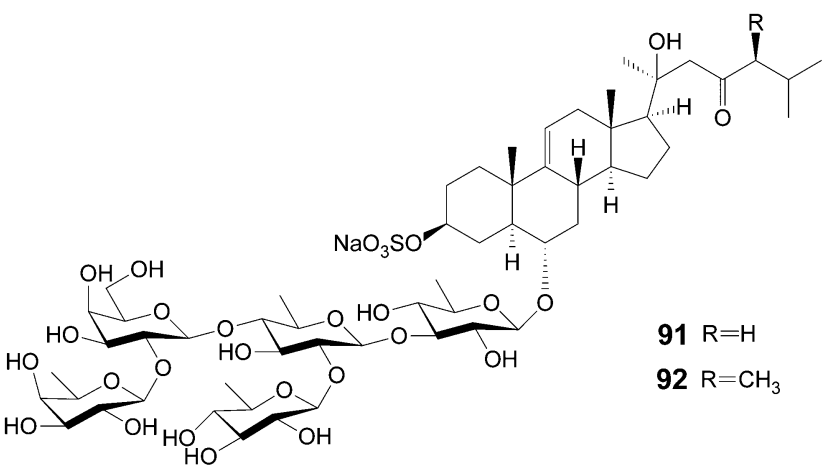

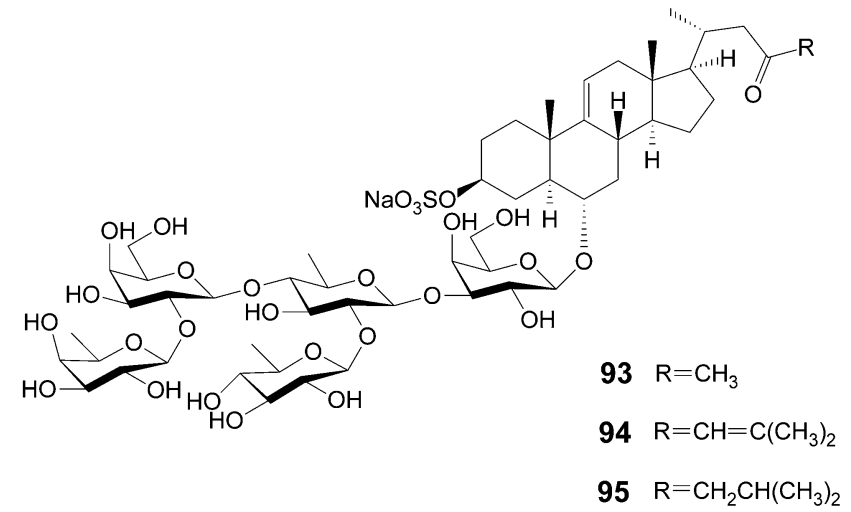

Hippasteriosides A, B, C and D (96) were isolated from starfish Hippasteria kurilensis (Kuril Islands, Okhotsk Sea). The compound (96) demonstrate a remarkable inhibition of the HT29 colony formation, suggesting its anti-cancerogenic properties. ${ }^{100}$ The asterosaponin, asteropsiside A (97) (starfish Asteropsis carinifera; Phong Bay, South Chinese Sea) inhibited the growth of the T-47D and RPMI-7951 tumor cell colonies in vitro. ${ }^{101}$ Lethasteriosides A (98) and B were isolated from the ethanolic extract of the Far Eastern starfish Lethasterias fusca. Glycoside (98) demonstrated inhibition of the T-47D, RPMI-795I and HCT-116 cells colony formations. ${ }^{102}$ Novaeguineside G, a new asterosaponine were isolated from the starfish Culcita novaeguineae (South China Sea), but the bioactivity has not been reported..$^{103}$ Astrosteriosides A (99), B, C and D (100) were found in Vietnamese starfish Astropecten monacanthus (Cát Bà Island, Vietnam). Compounds (99) and (100) exhibited potent antiinflammatory activity. ${ }^{104}$ Two tetrasaccharides, $\beta$-D-quinovopyranosyl-( $(1 \rightarrow 2)-\beta$-D-fucopyranosyl-( $1 \rightarrow 4)$-[ $\beta$-D-fucopyranosyl- $(1 \rightarrow$ 2)]- $\alpha$-D-quinovopyranose and methyl $\beta$-D-quinovopyranosyl- $(1 \rightarrow$ 2 )- $\beta$-D-fucopyranosyl-( $1 \rightarrow 4)$-[ $\beta$-D-fucopyranosyl-( $1 \rightarrow 2)]$ - $\alpha$-D-quinovopyranoside, were isolated from the starfish Asterias rollestoni (Yellow Sea, China), contain an $\alpha$-D-quinovose moiety. However, the bioactivity has not been reported for these compounds. ${ }^{105}$

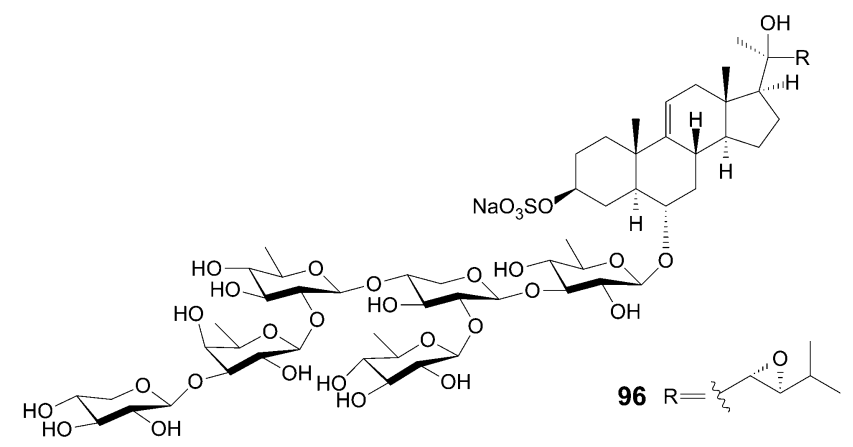




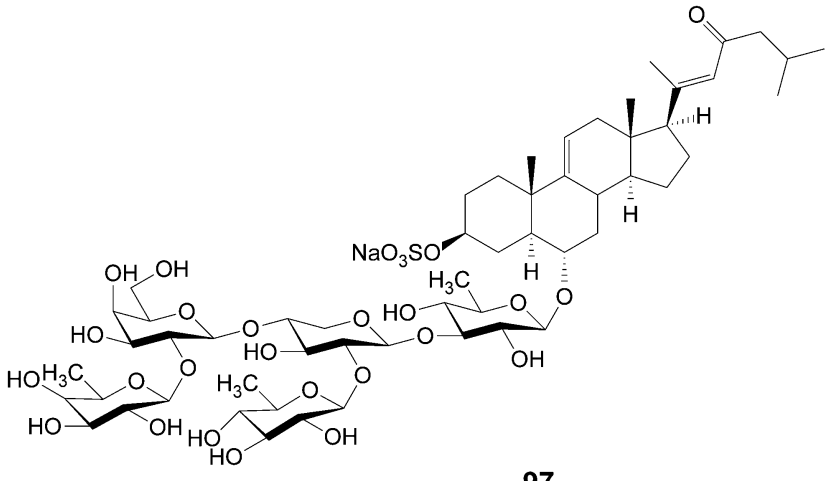

97
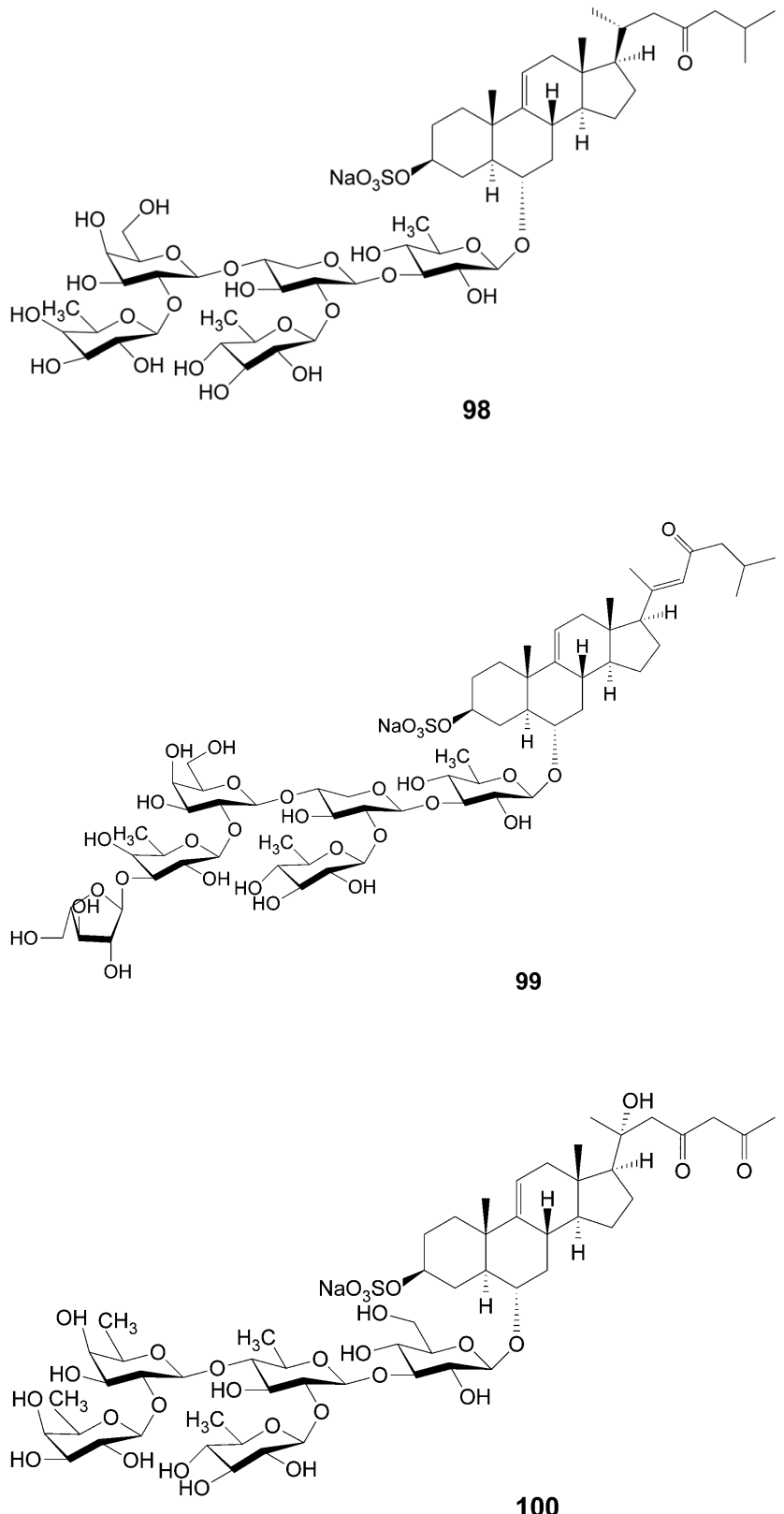

\subsection{Peptides}

Centrocins 1 (101) and 2 (102), two novel dimeric peptides from the Norwegian green sea urchin Strongylocentrotus droebachiensis (Tromsø, Norway) exhibiting antimicrobial activity. ${ }^{106}$

$$
\begin{aligned}
& \mathrm{Br} \\
& \text { GWFKKTFHKVSHAVKSGIHAGQRGCSALGF } \\
& \text { DLRGACAAAHAL } \\
& 101 \\
& \mathrm{Br} \\
& \text { SWFSRTVHNVGNAVRKGIHAGQGVCSGLGL } \\
& \text { DLRAICAGAHAL }
\end{aligned}
$$

102

\subsection{Sphingolipids and fatty acids}

The galactocerebrosides (BAC-1, BAC-2, BAC-4 and BAC-4-4a) and the glucocerebroside (BAC-2a) were isolated for the first time from the sea cucumber Bohadschia argus (Okinawa, Japan). ${ }^{\mathbf{1 0 7 , 1 0 8}}$ BAC-2a has a polar head group (glucose). The bioactivity has not been studied. ${ }^{108}$ A novel cerebroside, AMC-2 (103) isolated from the sea cucumber Acaudina molpadioides (Zhejiang Province, China), reduced the levels of hepatic triglyceride and of total cholesterol in fatty liver mice by down regulation of stearoyl-CoA desaturase. ${ }^{109}$ Two unsaturated fatty acids, identified as (7Z)-octadecenoic acid (104) and $(7 Z, 10 Z)$ octadecadienoic acid (105) isolated from the body wall of sea cucumber Stichopus japonicus (Gangneung market, Korea), showed a potent $\alpha$-glucosidase inhibitory activity. ${ }^{\mathbf{1 1 0}}$ The fatty

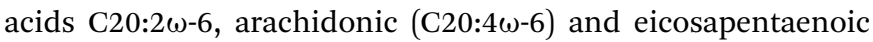
$(\mathrm{C} 20: 5 \omega-3)$ were isolated for the first time from the sea cucumber Athyonidium chilensis (Las Cruces, Chile), but the bioactivity has not been reported for these compounds. ${ }^{111}$

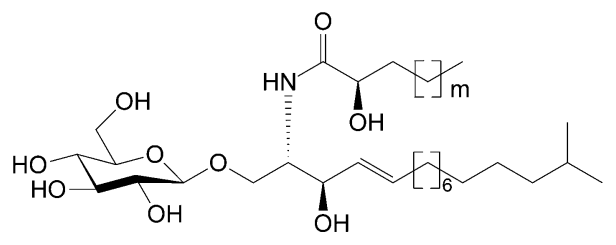

$103 \mathrm{~m}=18,19,20$

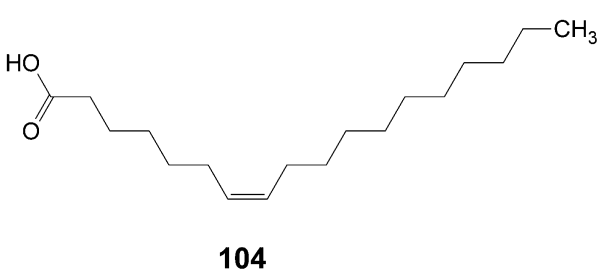




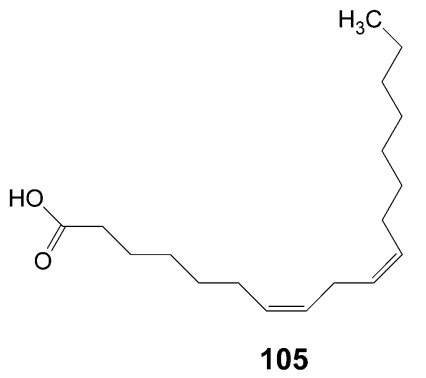

A hematoside-type ganglioside (glycosphingolipids), LLG-1, was reported for the first time with origin in the starfish Linckia laevigata (Okinawa, Japan), however no bioactivity was associated with this compound. ${ }^{\mathbf{1 1 2}}$ Sixteen new compounds were isolated from the pyloric caeca of the starfish Protoreaster nodosus (Okinawa, Japan), and identified as PNC-1-3a, PNC-1-3b, PNC-14a/PNC-1-4b, PNC-1-4c, PNC-1-5b, PNC-1-5c, PNC-1-6a, PNC-16b/PNC-1-6c, PNC-1-6d, PNC-1-7a, PNC-1-7b, PNC-1-8a, PNC-1$8 \mathrm{c}$, and PNC-1-10, but their bioactivity has not been reported. ${ }^{113}$ Three new ganglioside molecular species, termed PNG-1, PNG2A, and PNG-2B were isolated from the starfish Protoreaster nodosus (Okinawa, Japan) pyloric caeca. PNG-2A and PNG-2B represent the first GM4 elongation products in nature, but no bioactivity has been associated with these compounds. ${ }^{\mathbf{1 1 4}}$

\subsection{Carotenoids, quinones, spinochromes and pigments}

Four carotenoids, 4-ketodeepoxyneoxanthin, 4-keto-4'-hydroxydiatoxanthin, 3'-epigobiusxanthin, and 7,8-dihydrodiadinoxanthin were isolated from the crown-of-thorns starfish Acanthaster planci (Ootsuki coast, Japan), but no bioactivity has been reported for these compounds. ${ }^{\mathbf{1 1 5}}$

The polyhydroxylated naphthoquinone pigments, aminopentahydroxynaphthoquinone (106) $\left(\mathrm{C}_{10} \mathrm{H}_{7} \mathrm{NO}_{7}\right)$ and acetylaminotrihydroxynaphthoquinone $(\mathbf{1 0 7})\left(\mathrm{C}_{10} \mathrm{H}_{9} \mathrm{NO}_{6}\right)(106$ and 107 structural formula not reported) were isolated from the Strongylocentrotus nudus (Yellow sea, China) purple sea urchin. Compounds (106) and (107) exhibited moderate antioxidant activity, $\mathrm{Fe}^{2+}$ chelating, lipid peroxidation inhibition and oxidative stress protection properties. ${ }^{116}$ Six sea urchin pigments, spinochrome monomers B (108) and D (109), three spinochrome dimers, anhydroethylidene-6,6'-bis(2,3,7-trihydroxynaphthazarin) (110) and its isomer (111), and ethylidene6,6'-bis(2,3,7-trihydroxynaphthazarin) (112) as well as one pigment that was preliminary identified as a spinochrome dimer with the structural formula $\mathrm{C}_{22} \mathrm{H}_{16} \mathrm{O}_{16}$ (113) (108-113 structural formula not reported) were isolated from the sea urchin Strongylocentrotus droebachiensis (Barents Sea, Russia) and revealed antioxidant activity. ${ }^{117}$ Compounds (108) and (109) had anti-allergic effects in rabbits. ${ }^{\mathbf{1 1 7 , 1 1 8}}$

A crinoid Proisocrinus ruberrimus (Okinawa Trough, Japan) yielded the brominated anthraquinone pigments, proisocrinins A-F, to which no bioactivity has been reported. ${ }^{119}$ Two phenanthroperylenequinone, gymnochromes E (114) and F (115) were isolated from the crinoid Holopus rangii collected from Curacao south coast. Compound (114) showed cytotoxic activity toward the NCI/ADR-Res and inhibited histone deacetylase-1.
Compound (115) was a moderate inhibitor of myeloid cell leukemia sequence 1 (MCL-1) binding to Bak. ${ }^{\mathbf{1 2 0}}$<smiles>CCC[C@H](O)Cc1c(Br)c(O)c2c(=O)c3c(O)cc(O)c4c5c(O)cc(O)c6c(=O)c7c(O)c(Br)c(C[C@H](C)O)c8c1c2c(c34)c(c65)c78</smiles>

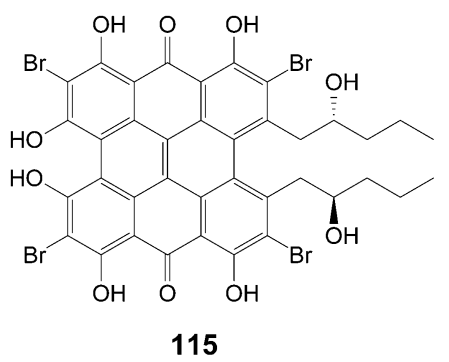

\subsection{Other bioactive compounds}

Two sulfated alkene, (5Z)-dec-5-en-1-yl sulfate (116) and (3E)dec-3-en-1-yl sulfate (117), (Sea Cucumber Apostichopus Japonicus, Liaoning Province, China) showed antibacterial, antifungal and cytotoxic activities (A549, MG63 and U251 cells). ${ }^{62}$

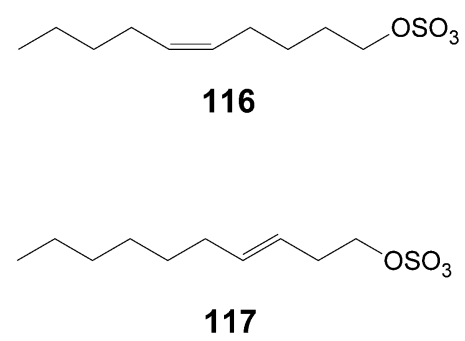

Isolated from the sea urchin Glyptocidaris crenularis (Dalian, Yellow Sea, China) were the compounds $N$-acyl taurine (118) and 1-( $\beta$-D-ribofuranosyl)-1,2,4-triazole (119), which exhibited a weak cytotoxicity against brine shrimp larvae. ${ }^{121}$

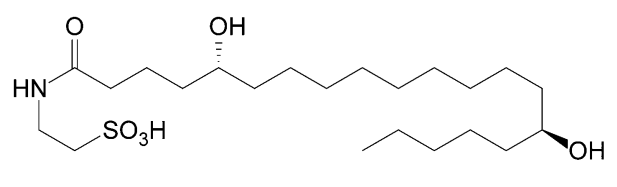

118

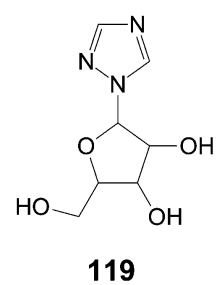


Ophiodilactones A (120) and B (121), two tetrameric phenylpropanoids (brittle star Ophiocoma scolopendrina) exhibited moderate cytotoxic activity against P388 murine leukemia cells. $^{122}$

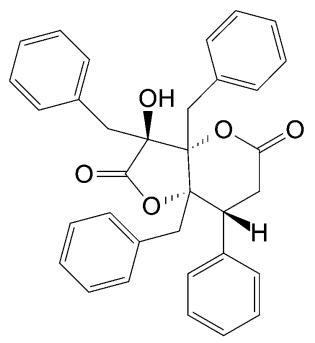

120

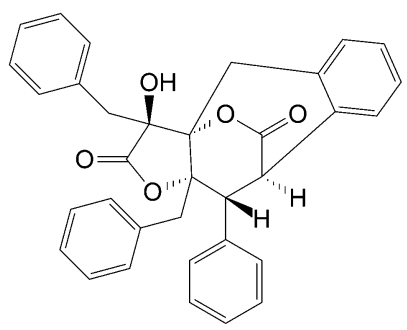

121

\section{Conclusion}

More than two hundred natural compounds with origin in echinoderms species were discovered between 2009 and 2013 and they are described in this review. Of the 240 natural compounds discovered, only $50 \%$ of the compounds were associated with some sort of bioactivity. For the remaining 50\% of compounds, their bioactivity has not yet been either studied or reported. The most studied BC were the triterpene glycosids and steroids, showing antifungal activity and cytotoxicity against human tumor cell lines as the main biological properties.

A higher number of new natural compounds has been isolated from the starfishes and sea cucumbers. This tendency does not mean necessarily that Asteroidea and Holothuroidea classes represent the source with larger diversity of natural compounds than other echinoderm class. Species from these classes seem to be more popular among researchers, probably due to the bioprospecting studies, which eventually discriminates other marine invertebrates, such as sea urchins, crinoids and brittle stars. Therefore, further studies should be pursued on less studied species or even in non-studied at all, especially from Echinoidea, Crinoidea and Ophiuroidea, in order to screen and search for other new potential BC. In addition, more attempts on screening other biological properties rather than those already carried out in natural compounds, could demonstrate other potentialities; a BC with no antifungal activity could exhibit others activities such as anti-tumor and anti-inflammatory. It is also important to emphasize that the studies on mechanisms of action of the discovered bioactive compounds are still lacking. The majority of published studies do not include such any information. Since the mechanisms of action for BC are sometimes unknown, and many of their biological properties screened in vitro are not confirmed when tested in vivo the majority of bioactive compounds isolated from marine organisms do not attain a stage of clinical trials.

\section{Declaration of interest}

The authors report no declarations of interest.

\section{Acknowledgements}

This work was supported by the Portuguese Science Foundation (Fundação para a Ciência e Tecnologia), through individual research grants references SFRH/BPD/73781/2010 and SFRH/ BPD/65410/2009 under QREN - POPH funds, co-financed by the European Social Fund and Portuguese National Funds from MCTES.

\section{References}

1 R. Montaser and H. Luesch, Future Med. Chem., 2011, 3, 1475-1489.

2 S.-K. Kim and I. Wijesekara, J. Funct. Foods, 2010, 2, 1-9.

3 D.-H. Ngo, T.-S. Vo, D.-N. Ngo, I. Wijesekara and S.-K. Kim, Int. J. Biol. Macromol., 2012, 51, 378-383.

4 M. Sugumaran and W. E. Robinson, Mar. Drugs, 2010, 8, 2906-2935.

5 J. Blunt, J. Buckingham and M. Munro, in Handbook of Marine Natural Products, ed. E. Fattorusso, W. H. Gerwick and O. Taglialatela-Scafati, Springer, Netherlands, Dordrecht, 2012, pp. 3-54.

6 A. M. S. Mayer, A. D. Rodríguez, O. Taglialatela-Scafati and N. Fusetani, Mar. Drugs, 2013, 11, 2510-2573.

7 S. Bordbar, F. Anwar and N. Saari, Mar. Drugs, 2011, 9, 17611805.

8 D. M. Pereira, P. Valentão, N. Teixeira and P. B. Andrade, Food Chem., 2013, 141, 2412-2417.

9 R. C. Brusca and G. J. Brusca, Invertebrates, Sinauer Associates, Sunderland, MA, 2003, pp. 808-826.

10 D. L. Pawson, Zootaxa, 2007, 1668, 749-764.

11 M. C. Leal, C. Madeira, C. A. Brandão, J. Puga and R. Calado, Molecules, 2012, 17, 9842-9854.

12 P. Samuel, L. Prince and P. Prabakaran, World J. Sci. Technol., 2011, 1, 74-91.

13 B. Uzair, Z. Mahmood and S. Tabassum, BioImpacts, 2011, 1, 203-211.

14 S. Gupta and N. Abu-Ghannam, Trends Food Sci. Technol., 2011, 22, 315-326.

15 C. H. Ho, J. Piotrowski, S. J. Dixon, A. Baryshnikova, M. Costanzo and C. Boone, Curr. Opin. Chem. Biol., 2011, 15, 66-78.

16 P. Laurienzo, Mar. Drugs, 2010, 8, 2435-2465.

17 J. Yasuhara-Bell and Y. Lu, Antiviral Res., 2010, 86, 231-240. 
18 V. Seidel, in Natural Products Isolation, ed. S. D. Sarker, Z. Latif and A. I. Gray, Humana Press Inc., 2006, pp. 27-46.

19 F. J. Schmitz, B. F. Bowden and S. I. Toth, Antitumor and cytotoxic compounds from marine organisms, in Marine Biotechnology, Volume I: Pharmaceutical and Bioactive Natural Products, eds. D. H. Attaway and O. R. Zaborsky, Plenum Press, 1993, pp. 197-308.

20 J. W. Blunt, B. R. Copp, R. A. Keyzers, M. H. G. Munro and M. R. Prinsep, Nat. Prod. Rep., 2013, 30, 237-323.

21 J. W. Blunt, B. R. Copp, R. A. Keyzers, M. H. G. Munro and M. R. Prinsep, Nat. Prod. Rep., 2012, 29, 144-222.

22 J. W. Blunt, B. R. Copp, M. H. G. Munro, P. T. Northcote and M. R. Prinsep, Nat. Prod. Rep., 2011, 28, 196-268.

23 M. F. de Jesus Raposo, R. M. S. C. de Morais and A. M. M. B. de Morais, Life Sci., 2013, 93, 479-486.

24 M. E. Rateb and R. Ebel, Nat. Prod. Rep., 2011, 28, 290344.

25 U. Grienke, J. Silke and D. Tasdemir, Food Chem., 2014, 142, 48-60.

26 P. A. Harnedy and R. J. FitzGerald, J. Funct. Foods, 2012, 4, 6-24.

27 G. Dong, T. Xu, B. Yang, X. Lin, X. Zhou, X. Yang and Y. Liu, Chem. Biodiversity, 2011, 8, 740-791.

28 H. J. V. Cleave, Invertebrate Zoology, McGraw-Hill, 1931, pp. 165-181.

29 R. D. Barnes, Invertebrate Zoology, Holt-Saunders International, 1982, pp. 981-997.

30 C. H. Edmondson, Autonomy and regeneration in Hawaiian starfishes, Bishop Museum Occasional Papers, 1935, 11, 3-20.

31 W. K. Fisher, Biol. Bull., 1925, 48, 171-175.

32 F. A. Mcalary, in 3rd California Islands Symposium, 1993.

33 F. R. Kille, Biol. Bull., 1942, 83, 55-66.

$34 \mathrm{~J}$. W. Nybakken and M. D. Bertness, Marine Biology: An Ecological Approach, Addison-Wesley, 1997, p. 174.

35 M. D. Candia Carnevali and F. Bonasoro, Microsc. Res. Tech., 2001, 55, 365-368.

36 Y. Achituv and E. Sher, Bull. Mar. Sci., 1991, 48, 670-679.

37 P. O. Ottesen and J. S. Lucas, Mar. Biol., 1982, 69, 223-233.

38 E. Oultsiadou and C. Chintiroglou, Cah. Biol. Mar., 2008, 49, 299-302.

39 T. K. Baumiller and C. G. Messing, Geological Society of America Abstracts with Programs, 2005, 37, 62.

40 H. C. Astley, J. Exp. Biol., 2012, 215, 1923-1929.

41 P. V. Mladenov, R. H. Emson, L. V. Colpit and I. C. Wilkie, J. Exp. Mar. Biol. Ecol., 1983, 72, 1-23.

42 T. M. McGovern, Mar. Ecol.: Prog. Ser., 2002, 230, 119-126.

43 W.-H. Yuan, Y.-H. Yi, H.-F. Tang, B.-S. Liu, Z.-L. Wang, G.-Q. Sun, W. Zhang, L. Li and P. Sun, Planta Med., 2009, 75, 168-173.

44 W.-H. Yuan, Y.-H. Yi, R.-X. Tan, Z.-L. Wang, G.-Q. Sun, M. Xue, H.-W. Zhang and H.-F. Tang, Planta Med., 2009, 75, 647-653.

45 H. Han, Y.-H. Yi, L. Li, B.-S. Liu, M.-X. Pan, B. Yan and X.-H. Wang, Chin. J. Nat. Med., 2009, 7, 346-350.

46 H. Han, Q.-Z. Xu, H.-F. Tang, Y.-H. Yi and W. Gong, Planta Med., 2010, 76, 1900-1904.
47 A. S. Antonov, S. A. Avilov, A. I. Kalinovsky, S. D. Anastyuk, P. S. Dmitrenok, V. I. Kalinin, S. Taboada, A. Bosh, C. Avila and V. a. Stonik, J. Nat. Prod., 2009, 72, 33-38.

48 H. Han, Q.-Z. Xu, Y.-H. Yi, W. Gong and B.-H. Jiao, Chem. Biodiversity, 2010, 7, 158-167.

49 C.-h. Xue, L.-f. Yu, P. Dong, J. Xu, Z.-j. Li and Y. Xue, J. Ocean Univ. Qingdao, 2010, 8, 60-65.

50 Z. Wang, H. Zhang, W. Yuan, W. Gong, H. Tang, B. Liu, K. Krohn, L. Li, Y. Yi and W. Zhang, Food Chem., 2012, 132, 295-300.

51 A. S. Antonov, S. A. Avilov, A. I. Kalinovsky, P. S. Dmitrenok, V. I. Kalinin, S. Taboada, M. Ballesteros and C. Avila, Nat. Prod. Res., 2011, 25, 1324-1333.

52 Q. Zhao, Z.-D. Liu, Y. Xue, J.-F. Wang, H. Li, Q.-J. Tang, Y.-M. Wang, P. Dong and C.-H. Xue, J. Zhejiang Univ., Sci., $B, 2011,12,534-544$.

53 A. S. Silchenko, A. I. Kalinovsky, S. A. Avilov, P. V. Andryjaschenko, P. S. Dmitrenok, E. a. Yurchenko and V. I. Kalinin, Nat. Prod. Commun., 2011, 6, 1075-1082.

54 V. P. Careaga, C. Muniain and M. S. Maier, Chem. Biodiversity, 2011, 8, 467-475.

55 J.-j. Zhang, Chin. Tradit. Herb. Drugs, 2011, 42, 1467-1472.

56 W.-p. Yuan, X. Liu, T.-j. Fan, Y.-g. Zhang, X.-k. Xia and C.-h. Liu, J. Shandong Univ., 2011, 34, 17-20.

57 Z. Wang, W. Gong, G. Sun, H. Tang, B. Liu, L. Li, Y. Yi and W. Zhang, Nat. Prod. Commun., 2012, 7, 1431-1434.

58 A. S. Silchenko, A. I. Kalinovsky, S. A. Avilov, P. V. Andryjaschenko, P. S. Dmitrenok, E. A. Martyyas and V. I. Kalinin, Nat. Prod. Commun., 2012, 7, 517-525.

59 A. S. Silchenko, A. I. Kalinovsky, S. A. Avilov, P. V. Andryjaschenko, P. S. Dmitrenok, E. a. Martyyas and V. I. Kalinin, Nat. Prod. Commun., 2012, 7, 845-852.

60 A. S. Silchenko, A. I. Kalinovsky, S. A. Avilov, P. V. Andryjaschenko, P. S. Dmitrenok, E. A. Martyyas and V. I. Kalinin, Nat. Prod. Commun., 2012, 7, 1157-1162.

61 A. S. Silchenko, A. I. Kalinovsky, S. A. Avilov, P. V. Andryjashchenko, P. S. Dmitrenok, V. I. Kalinin and V. a. Stonik, Biochem. Syst. Ecol., 2012, 44, 53-60.

62 A. S. Silchenko, A. I. Kalinovsky, S. A. Avilov, P. V. Andryjaschenko, P. S. Dmitrenok, E. A. Yurchenko and V. I. Kalinin, Nat. Prod. Res., 2012, 26, 1765-1774.

63 F. R. Melek, M. M. Tadros, F. Yousif, M. A. Selim and M. H. Hassan, Pharm. Biol., 2012, 50, 490-496.

64 H. Han, L. Li, Y.-h. Yi, X.-h. Wang and M.-x. Pan, Chin. Herb. Med., 2012, 4, 183-188.

65 V. P. Careaga, C. Bueno, C. Muniain, L. Alché and M. S. Maier, Nat. Prod. Res., 2012, 37-41.

66 A. S. Silchenko, A. I. Kalinovsky, S. A. Avilov, P. V. Andryjashchenko, P. S. Dmitrenok, V. I. Kalinin, S. Taboada and C. Avila, Biochem. Syst. Ecol., 2013, 51, 45-49.

67 A. S. Silchenko, A. I. Kalinovsky, S. A. Avilov, P. V. Andryjaschenko, P. S. Dmitrenok, E. S. Menchinskaya, D. L. Aminin and V. I. Kalinin, Nat. Prod. Res., 2013, 27, 1776-1783.

68 A. S. Silchenko, A. I. Kalinovsky, S. A. Avilov, P. V. Andryjaschenko, P. S. Dmitrenok, E. A. Martyyas and V. I. Kalinin, Nat. Prod. Commun., 2013, 8, 1053-1058. 
69 A. S. Silchenko, A. I. Kalinovsky, S. A. Avilov, P. V. Andryjaschenko, P. S. Dmitrenok, E. A. Martyyas, V. I. Kalinin, P. Jayasandhya, G. C. Rajan and K. P. Padmakumar, Nat. Prod. Commun., 2013, 8, 301-310.

70 A. Silchenko, A. S. Silchenko and S. Alexandra, Nat. Prod. Commun., 2013, 8, 1527-1534.

71 E. V. Levina, A. I. Kalinovsky and P. V. Dmitrenok, Russ. J. Bioorg. Chem., 2009, 35, 123-130.

72 E. V. Levina, D. L. Aminin, S. N. Kovalchuk, V. B. Kozhemyako, S. A. Dyshlovoi, A. I. Kalinovskii and P. S. Dmitrenok, Russ. J. Bioorg. Chem., 2010, 36, 233-239.

73 A. A. Kicha, N. V. Ivanchina, A. I. Kalinovsky, P. S. Dmitrenok and V. A. Stonik, Steroids, 2009, 74, 238-244.

74 A. A. Kicha, N. V. Ivanchina, A. I. Kalinovsky, P. S. Dmitrenok and A. V. Smirnov, Russ. J. Bioorg. Chem., 2009, 35, 504-509.

75 N. Ma, H. F. Tang, F. Qiu, H. W. Lin, X. R. Tian and W. Zhang, Chin. Chem. Lett., 2009, 20, 1231-1234.

76 T. T. T. Huong, C. Q. Truyen, P. Q. Long, C. V. Minh, A. A. Kicha, N. V. Ivanchina, I. Anatoly, P. S. Dmitrenok and V. A. Stonik, Journal of Chemistry, 2009, 47, 374-378.

77 E. V. Levina, A. I. Kalinovsky, P. S. Dmitrenok and D. L. Aminin, Nat. Prod. Commun., 2009, 4, 1041-1046.

78 H.-W. Liu, J.-K. Li, D.-W. Zhang, J.-C. Zhang, X. Zhang, X.-H. Song, Y. Xia, N.-L. Wang, X.-S. Yao and G.-P. Cai, Nat. Prod. Res., 2010, 24, 294-299.

79 N. V. Ivanchina, A. A. Kicha, T. T. T. Huong, A. I. Kalinovsky, P. S. Dmitrenok, I. G. Agafonova, P. Q. Long and V. A. Stonik, Steroids, 2010, 75, 897-904.

80 E. V. Levina, A. I. Kalinovsky, P. S. Dmitrenok, E. A. Martyyas and V. A. Stonik, Nat. Prod. Commun., 2010, 5, 1737-1742.

81 N. Ma, H.-F. Tang, F. Qiu, H.-W. Lin, X.-R. Tian and M.-N. Yao, J. Nat. Prod., 2010, 73, 590-597.

82 T. V. Malyarenko, A. A. Kicha, N. V. Ivanchina, A. I. Kalinovsky, P. S. Dmitrenok and A. V. Smirnov, Russ. J. Bioorg. Chem., 2010, 36, 755-761.

83 Y. Peng, J. Zheng, R. Huang, Y. Wang, T. Xu, X. Zhou, Q. Liu, F. Zeng, H. Ju, X. Yang and Y. Liu, Chem. Pharm. Bull., 2010, 58, 856-858.

84 X.-W. Yang, X.-Q. Chen, G. Dong, X.-F. Zhou, X.-Y. Chai, Y.-Q. Li, B. Yang, W.-D. Zhang and Y. Liu, Food Chem., 2011, 124, 1634-1638.

85 T. V. Malyarenko, A. A. Kicha, N. V. Ivanchina, A. I. Kalinovsky, P. S. Dmitrenok, S. P. Ermakova and V. A. Stonik, Steroids, 2011, 76, 1280-1287.

86 A. A. Kicha, N. V. Ivanchina, T. V. Malyarenko, A. I. Kalinovskii and P. S. Dmitrenok, Chem. Nat. Compd., 2012, 48, 806-809.

87 E. V. Levina, A. I. Kalinovskii, S. P. Ermakova and P. S. Dmitrenok, Russ. J. Bioorg. Chem., 2012, 38, 520-525.

88 R. S. Popov, N. V. Ivanchina, A. A. Kicha, T. B. Malyarenko, A. I. Kalinovskii and P. S. Dmitrenok, Chem. Nat. Compd., 2013, 49, 286-290.

89 N. V. Palyanova, T. M. Pankova, M. V. Starostina, A. A. Kicha, N. V. Ivanchina and V. A. Stonik, Mar. Drugs, 2013, 11, 1440-1455.
90 S. V. Dyck, P. Gerbaux and P. Flammang, Comp. Biochem. Physiol., Part B: Biochem. Mol. Biol., 2009, 152, 124-134.

91 M. Li, Z.-H. Miao, Z. Chen, Q. Chen, M. Gui, L.-P. Lin, P. Sun, Y.-H. Yi and J. Ding, Ann. Oncol., 2010, 21, 597-607. 92 S. V. Dyck, P. Gerbaux and P. Flammang, Mar. Drugs, 2010, 8, 173-189.

93 H.-F. Tang, G. Cheng, J. Wu, X.-L. Chen, S.-Y. Zhang, A.-D. Wen and H.-W. Lin, J. Nat. Prod., 2009, 72, 284-289.

94 X. G. Ma, H. F. Tang, C. H. Zhao, N. Ma, M. N. Yao and A. D. Wen, Chin. Chem. Lett., 2009, 20, 1227-1230.

95 A. A. Kicha, N. V. Ivanchina, T. T. T. Huong, A. I. Kalinovsky, P. S. Dmitrenok, S. N. Fedorov, S. A. Dyshlovoy, P. Q. Long and V. A. Stonik, Bioorg. Med. Chem. Lett., 2010, 20, 38263830 .

96 A. A. Kicha, N. V. Ivanchina, T. T. T. Huong, A. I. Kalinovsky, P. S. Dmitrenok and P. Q. Long, Russ. Chem. Bull., 2010, 59, 2133-2136.

97 N. V. Ivanchina, T. V. Maliarenko, A. A. Kicha, A. I. Kalinovskil̆, P. S. Dmitrenok and S. P. Ermakova, Bioorg. Khim., 2011, 37, 559-566.

98 N. V. Ivanchina, T. V. Malyarenko, A. A. Kicha, A. I. Kalinovsky, P. S. Dmitrenok and S. P. Ermakova, Russ. J. Bioorg. Chem., 2011, 37, 499-506.

99 I. H. Hwang, D. W. Kim, S. J. Kim, B. S. Min, S. H. Lee, J. K. Son, C.-H. Kim, H. W. Chang and M. Na, Chem. Pharm. Bull., 2011, 59, 78-83.

100 A. A. Kicha, A. I. Kalinovsky, N. V. Ivanchina, T. V. Malyarenko, P. S. Dmitrenok, S. P. Ermakova and V. A. Stonik, Chem. Biodiversity, 2011, 8, 166-175.

101 T. V. Malyarenko, A. A. Kicha, N. V. Ivanchina, A. I. Kalinovskii, P. S. Dmitrenok, S. P. Ermakova and C. V. Minkhb, Russ. Chem. Bull., 2012, 61, 1986-1991.

102 N. V. Ivanchina, A. I. Kalinovsky, A. A. Kicha, T. V. Malyarenko, P. S. Dmitrenok, S. P. Ermakova and V. A. Stonik, Nat. Prod. Commun., 2012, 7, 853-858.

103 J.-J. Zhang, J. Wu and K.-Y. Wang, J. Chin. Med. Mater., 2012, 35, 1435-1438.

104 N. P. Thao, N. X. Cuong, B. T. T. Luyen, N. V. Thanh, N. X. Nhiem, Y.-s. Koh, B. M. Ly, N. H. Nam, P. V. Kiem, C. V. Minh and Y. H. Kim, J. Nat. Prod., 2013, 76, 1764-1770.

105 G.-y. Zhang, H.-H. Ren, Y.-B. Zhang, L.-Q. Ma, Y.-L. Yang and S. Wang, Biochem. Syst. Ecol., 2013, 51, 203-206.

106 C. Li, T. Haug, M. K. Moe, O. B. Styrvold and K. Stensvåg, Dev. Comp. Immunol., 2010, 34, 959-968.

107 Y. Ikeda, M. Inagaki, K. Yamada, X. W. Zhang, B. Zhang, T. Miyamoto and R. Higuchi, Chem. Pharm. Bull., 2009, 57, 315-317.

108 Y. Ikeda, M. Inagaki, K. Yamada, T. Miyamoto, R. Higuchi and O. Shibata, Colloids Surf., B, 2009, 72, 272-283.

109 J. Xu, Y.-M. Wang, T.-Y. Feng, B. Zhang, T. Sugawara and C.-H. Xue, Biosci., Biotechnol., Biochem., 2011, 75, 1466-1471.

110 T. H. Nguyen, B. H. Um and S. M. Kim, J. Food Sci., 2011, 76, H208-H214.

111 V. P. Careaga, C. Muniain and M. S. Maier, Nat. Prod. Res., 2013, 27, 638-646.

112 M. Inagaki, T. Saito, T. Miyamoto and R. Higuchi, Chem. Pharm. Bull., 2009, 57, 204-206. 
113 K. Pan, M. Inagaki, N. Ohno, C. Tanaka, R. Higuchi and T. Miyamoto, Chem. Pharm. Bull., 2010, 58, 470-474.

114 K. Pan, C. Tanaka, M. Inagaki, R. Higuchi and T. Miyamoto, Mar. Drugs, 2012, 10, 2467-2480.

115 T. Maoka, N. Akimoto, Y. Terada, S. Komemushi, R. Harada, N. Sameshima and Y. Sakagami, J. Nat. Prod., 2010, 73, 675-678.

116 D.-Y. Zhou, L. Qin, B.-W. Zhu, X.-D. Wang, H. Tan, J.-F. Yang, D.-M. Li, X.-P. Dong, H.-T. Wu, L.-M. Sun, X.-L. Li and Y. Murata, Food Chem., 2011, 129, 1591-1597.

117 A. N. Shikov, V. I. Ossipov, O. Martiskainen, O. N. Pozharitskaya, S. a. Ivanova and V. G. Makarov, J. Chromatogr., 2011, 1218, 9111-9114.
118 O. N. Pozharitskaya, A. N. Shikov, M. N. Makarova, S. A. Ivanova, V. M. Kosman, V. G. Makarov, V. Bazgier, K. Berka, M. Otyepka and J. Ulrichová, Planta Med., 2013, 79, 1698-1704.

119 K. Wolkenstein, W. Schoefberger, N. Müller and T. Oji, J. Nat. Prod., 2009, 72, 2036-2039.

120 H. V. Kemami Wangun, A. Wood, C. Fiorilla, J. K. Reed, P. J. McCarthy and A. E. Wright, J. Nat. Prod., 2010, 73, 712-715.

121 X. Zhou, T. Xu, K. Wen, X.-W. Yang, S.-H. Xu and Y. Liu, Biosci., Biotechnol., Biochem., 2010, 74, 1089-1091.

122 R. Ueoka, T. Fujita and S. Matsunaga, J. Org. Chem., 2009, 74, 4396-4399. 